\section{Conservation Problems of Traditional Architectural Heritage in Terms of Life of a Mansion; Remzi Bey Mansion in Bursa-Orhaneli}

Z. Sena Güneş Kaya, ORCID: 0000-0002-1595-6991

Elif Özlem Aydın², ORCID: 0000-0003-1902-577X

\section{Keywords}

Bursa, Orhaneli, Vernacular Architectural Heritage, Conservation, Remzi Bey Mansion

\section{Abstract}

Orhaneli is a settlement which has been founded in the Roman era, where has located in the southern part of Bursa at the Marmara Region. Orhaneli is one of the Highland Region districts with the other three regions, at the southern part of Bursa City. Urban texture has consisted of buildings which were constructed with vernacular materials and traditional techniques until about half a century ago. Original texture of Orhaneli has transformed into multi-storey concrete constructions nowadays, as it is visible at many other Anatolian towns and cities. There are still preserved traditional houses, despite the disappearing of original texture.

Remzi Bey Mansion is one of the most remarkable buildings of Orhaneli which can provides estimation about original texture of the town. The mansion is a four-iwaned building with a central hall which was built with local materials and traditional techniques. New houses were constructed with similar identity in the garden and new spaces were added in the need to contemporary lifestyle. The original plan has lost after the division of the property. Maintenance and repair has become an issue. Conservation issues of traditional architectural heritage of Orhaneli are specified in terms of Remzi Bey Mansion in this study.

\section{Article Information}

Received: 17.04.2020

Accepted: 28.07 .2020

Available Online: 29.07.2020

Article Classification: Research Article

1. Department of Architecture, Istanbul University, Istanbul,

Turkey, zsgunes@istanbul.edu.tr

2. Department of Architecture, Gebze Technical University, Kocaeli, Turkey, ozlemoral@gtu.edu.tr 


\section{Bir Konağın Yaşamı Üzerinden Geleneksel Mimari Mirasın Koruma Sorunları; Bursa İli Orhaneli İlçesinde Yer Alan Remzi Bey Konağ1}

Z. Sena Güneş Kaya1 ${ }^{1}$ ORCID: 0000-0002-1595-6991

Elif Özlem Aydın², ORCID: 0000-0003-1902-577X

\section{Anahtar Sözcükler}

Bursa, Orhaneli, Yerel Mimari

Miras, Koruma, Remzi Bey Konağ1
$\ddot{O} z$

Kuruluşu Roma İmparatorluğu'na uzanan bir yerleşim olan Orhaneli, Marmara Bölgesi'nin güneyinde yer alan Bursa'nın bir ilçesidir. Kendisinden ayrılan diğer üç ilçe ile birlikte Uludağ'ın güneyinde kalan Dağ Yöresi'ni meydana getirirler. Yarım asırdan kısa süre öncesine kadar yerel malzemeler ve geleneksel yapım teknikleriyle üretilen yapıların hakim olduğu bir dokuya sahiptir. Anadolu'nun pek çok yerleşimi gibi Orhaneli'nin de özgün tarihi dokusu kısa sürede çok katlı yapılar ile yer değiştirmiştir. Kaybolan dokuya rağmen, zamana direnen tekil yapılar hala mevcuttur.

Orhaneli’ndeki özgün kentsel doku hakkında fikir verebilecek belki de en gösterişli yapılardan biri Remzi Bey Konağı'dır. Konak, yerel malzemeler ve geleneksel yapım teknikleri ile inşa edilmiş dört eyvanlı merkezi sofalı bir yapıdır. İhtiyaçlar doğrultusunda bahçesine benzer kimlikli yeni konutlar ve yapıya çağdaş yaşam koşullarının gereği mekanlar eklenmiştir. Mülkiyet paylaşımı sonucu ikiye bölünmüş yapıda özgün plan şemasından uzaklaşılmış ve bakım onarım bir sorun haline gelmeye başlamıştır. Remzi Bey Konağı üzerinden Bursa Orhaneli ilçesinde yer alan mimari mirasın koruma sorunları bu çalışmada ele alınmıştır.

\section{Makale Bilgileri}

\author{
Alınd1: 17.04.2020 \\ Kabul edildi: 28.07.2020 \\ Erişilebilir: 29.07.2020
}

Makale Kategorisi: Özgün Araştırma Makalesi

1. Mimarlık Bölümü, İstanbul Üniversitesi, İstanbul, Türkiye, zsgunes@istanbul.edu.tr

2. Mimarlık Bölümü, Gebze Teknik Üniversitesi, Kocaeli, Türkiye, ozlemoral@gtu.edu.tr 


\section{GİRIŞ̧ (INTRODUCTION)}

Bursa ilinin güneyinde, Uludağ'ın eteklerinde yer alan Orhaneli, kısa süre öncesine kadar yerel malzemeler ve geleneksel yapım teknikleriyle üretilen yapıların hakim olduğu bir dokuya sahiptir. Anadolu'nun pek çok yerleşimi gibi Orhaneli'nin de özgün tarihi dokusu çok katlı yapılar ile hızlı bir şekilde yer değiştirmiştir. Kaybolan yerleşim dokusuna rağmen, zamana direnen tekil yapılar hala mevcuttur. Bu çalısmanın amacı, geleneksel bir dokunun parçası olan önemli bir yapının fiziksel ve tarihi verilerini okumaktır.

Orhaneli'nin bir parçası olduğu Dağ Yöresi'nin sosyal, kültürel ve tarihi değerleri üzerine derin araştırmalar yapılmıştır (Dikmen, 2011; Dikmen, 2012; Gülbay, 2009; Kaplanoğlu, 2010; Onur, 2011; Schwertheim, 2014; Şahin, 2014). Ancak bu bölgede yakın zamana kadar geleneksel mimari üzerine geniş kapsamlı ve detaylı çalışmalar gerçekleştirilmemiştir. Bu nedenle Orhaneli genelinde, ilçe merkezi ve köylerini kapsayan geleneksel mimari araştırmaları ile üst ölçekteki geleneksel dokuya yönelik veriler toplanmaktadır. Çalışmalar sırasında Orhaneli konutlarının rölöveleri alınmakta, yerleşimin tarihine yönelik yazılı ve görsel arşivler taranmakta, yerel kişiler ile bilgi paylaşımı yapılmaktadır. Elde edilen bilgileri bir araya getirmeden önce, alan çalışması sırasında belgelenen tek bir yap1 özelinde yerleşim geneline dair değerlendirmeler yapılmıştır. Çünkü Orhaneli'ndeki özgün kentsel doku hakkında fikir verebilecek belki de en gösterişli yapılardan biri Remzi Bey Konağı'dır. Bu yapı, yerleşim genelindeki başka konutlar ile kıyaslandığında ölçek ve yapım sistemi açısından da genel niteliklerden farklıdır. Remzi Bey Konağ1 ${ }^{*}$ bu araştırma makalesinde, geçirdiği değişimler üzerinden irdelenerek Bursa Orhaneli ilçesinde yer alan mimari mirasın koruma sorunları sunulmuştur.

\section{YERLEŞİMİN TARİHÇESİ (THE HISTORY OF SETTLEMENT)}

Bursa’ya bağlı Orhaneli ilçesi, şehir merkezine uzak mesafede ve Uludağ’ın güneyinde kalan dört Dağ Yöresi ilçesinden biridir. Arkeolojik ve yazılı kaynakların desteklediğine göre (Gülbay, 2009, s.21; Şahin, Mert ve Şahin, 2011, s.103-114; Şahin, 2014, s.20-24.), eski ad1 Atranos olan Orhaneli'nin kuruluşu Roma İmparatoru Hadrianus (MS 2. yy) ile başlamaktadır (Schwertheim,

\footnotetext{
* Remzi Bey Konağı'nın belgeleme çalışmalarına GTÜ Mimarlık Bölümü lisans öğrencilerinden Araf Öykü Türken, Çiğdem Sevinir Şahan, Faruk Faydalı, F. Özgür Alabay, F. Fatih Helvacı, Fuat Aslan, Gülşen Sulu, Hatice Dursun, Hilal Özdemir, Işılay Uzun, Kübra Karaca, Muhammed Akgüler, Mustafa Özdemir, Osman Akin, Özge Aykol, R. Zeynep Kurtuluş, Salih Balcı, Sedat Yılmaz, Selin Taşdelen ve Sinem Dalgıç katılmıştır. Elde edilen veriler, yerel yönetim ile paylaşılmıştır.
} 
2014, s.11-19). Roma İmparatorluğu sonrasında Bizans İmparatorluğu yönetimine geçmiş, Osmanlı Beyliği egemenliğine ise 1325 yllında girmiştir (Cemiloğlu, 2005: 37-39; Kaplanoğlu, 2010: 165-166). Topçu'nun icmal defterleri üzerinde yaptığ 1 araştırmaya göre, oldukça geniş kapsamlı olan 15201521 tarihli icmal defterinde o tarihte kaza olan Atranos'un tamamına yakınının tımar köylerinden oluştuğu anlaşılmaktadır (Topçu, 2004, s.31-35). 1520-1530 yılları arasında, yerleşimin Hüdavendigar Vilayeti'nin 25 kazasından biri; 1831 yılında ise Merkez Sancağı'nın 8 kazasından biri olduğu görülmektedir (Emecen, 1998, s.285-286). Yerleşim 1870 yılında kaza statüsünden nahiye statüsüne düşürülmüştür (Dikmen, 2012, s.23-31). Köylerinin sayısı ise 1907 Yllı Salnamesi’nde 195 olarak belirtilmiştir (Delil ve Dinçel, 2013, c.1, s.263).

Orhaneli'nin kayıtlarda Atranos olarak geçen ismi 12 Kasım 1913 tarihli irade ile kaza adı Orhaneli, merkez kasaba ismi Beyce olacak şekilde değiştirilmiştir (Topçu, 2009, s.14-15). Bu tarihten sonra yerleşimin tarihini etkileyen en önemli olay 1920 yll Temmuz ayında başlayan ve 9 Eylül 1922 yılında sona ererken neredeyse tüm yerleşimi yangınla yok eden Yunan işgalidir (Dikmen, 2012, s.23-31). Yerleşimin en büyük ve zamanının en gösterişli yapılarından olan tescilli Remzi Bey Konağı da, Yunan yangınından zarar gören ticari işlevli "Remzi Bey'in Hanı"nın yerine aynı aile tarafindan inşa edilmiş konut işlevli bir yapıdır (KK1; KK2).

İlçe dokusuna ait 21 adet geleneksel konut ile iki adet anıtsal yapının (Durdu Bey Cami ve Taş Mektep) (Şekil 1) tescili ve tarihi ilçe merkezinin sit alanı olarak tanımlanması ile 2005 yılından itibaren Orhaneli, Bursa Kültür Varlıkları Koruma Kurulu ve çeşitli araştırmacılar tarafindan kültür envanteri çalışmalarının bir parçası haline gelmiştir. Kırsal ve kentsel yaşamda meydana gelen köklü değişiklikler ile geleneksel çevre, zaman içinde geçmişe ait kültürel bir değere dönüşmeye başlamıştır (Eres, 2013, s.439-443). Ayrıca tarihi yerleşimlerin uyumlu düzenini, mimari bütünlügünü, donatılarını koruyabilmiş alanlarının bütüncül ele alınarak korunması gerekliliği ile sivil mimarlık örneklerinin de envanter, belgeleme, koruma çalışmalarına dahil edilmesi gündeme gelmiştir. Ancak kültür envanteri çalışmaları sürerken, geleneksel sivil mimarlık örnekleri Türkiye'de en geç belgeleme kapsamına dahil edilen alanlardan olmuştur.

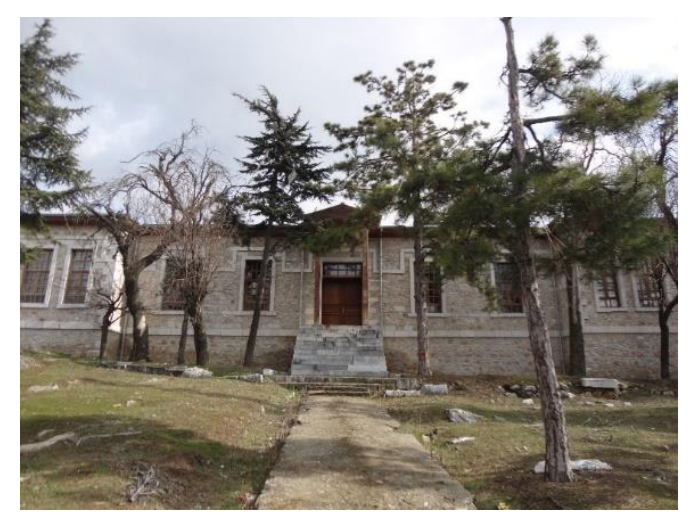

Şekil 1: Tescilli Taş Mektep (Güneş Kaya Arşivi, 2017).

Orhaneli'nin sahip olduğu ve çoğunu konutların oluşturduğu geleneksel çevre de, değişen yaşam koşulları ve gelişen ekonomik durum ile birlikte zaman içinde parçalarının çoğunu kaybetmiştir. Kalan tekil yapılar ve küçük yapı topluluklarından oluşan yerel nitelikli dokular, geçmişe ait kültürel 
birer değere ve aidiyeti hatırlatan anılara dönüşmeye başlamıştır. Orhaneli ilçe merkezinde 2005 yılında yürütülen tescil çalışmaları sırasında Bursa Kültür ve Tabiat Varlıklarını Koruma Bölge Kurulu tarafindan alınan 07.10.2005/985 numaralı karar ile tescilenmiş 23 yapıdan sekiz geleneksel konut, kentsel sit alanı içinde yer almaktadır (Şekil 2). Tescilli 23 adet yapı, yerleşim genelinde seçilmiş yapılardır. Bu yapılar haricinde, yer yer doku oluşturan ve geleneksel özelliklerini koruyan kültür varlıkları da mevcuttur.

Kırsal ve kentsel yaşam özelliklerini bir arada barındıran Orhaneli’de Remzi Bey Konağı da geçmişe referans veren bir kültürel değerdir. Kullanımı kesintisiz devam eden konak, küçülen aile yapısı ve bölünen mülkiyet sebebi ile değişimler geçirmiştir. Yapının geçirdiği değissimler üzerinden konağın özgün plan ve cephe düzenlerine ulaşılması hedeflenmiştir. Bu amaçla belgeleme çalışması ağırlıklı bir araştırma yürütülmüştür. Mevcut izlerin ve bilgilerin yetersiz kaldığ1 noktalarda yerleşimdeki diğer yapılar ile analojiye gidilmiş, bozulmalara neden olan başlıca etkenler yerleşim ölçeğinde değerlendirilmiştir.

\section{Yapının Konumu ve Tarihçesi}

Remzi Bey Konağı, tarihi kent merkezi dışında kalan 16 ada 11 parselde yer almakta olup, 5 envanter numarasıyla tescilli bir sivil mimarlık örneğidir (Şekil 3). Yap1 oldukça yıpranmış olmasına rağmen sahip olduğu mimari özellikleriyle yerel değerlere katkıda bulunmaktadır. Pek çok sivil mimarlık örneğinde olduğu gibi periyodik bakımların eksikliği, bozulmaların ana nedenidir. Ahşap malzemelerde biyolojik bozulmalar, sehimler, nem kaynaklı ayrışmalar; toprak malzemelerde kayıplar; yapı elemanlarının değiştirilmesi ve çă̆daş malzemeler ile eklemeler yapılması ise taşıyıcı sistemde sorunlar meydana getirmektedir. Konak; yapım sistemi ve avlulu yapısı ile ilçe geleneksel dokusunda sık rastlanan; üç köşe çıkması ve her iki katında dört eyvanlı merkezi sofalı planı ile de kendine has mimari özellikler sergilemektedir. Belgeleme ve bozulma tespitleri sayesinde yapının özgün karakterini yansıtan restitüsyon çizimleri üretilmiştir. Böylece yapının yansıttı̆̆ değerler net bir şekilde gün yüzüne çıkarılmıştır.

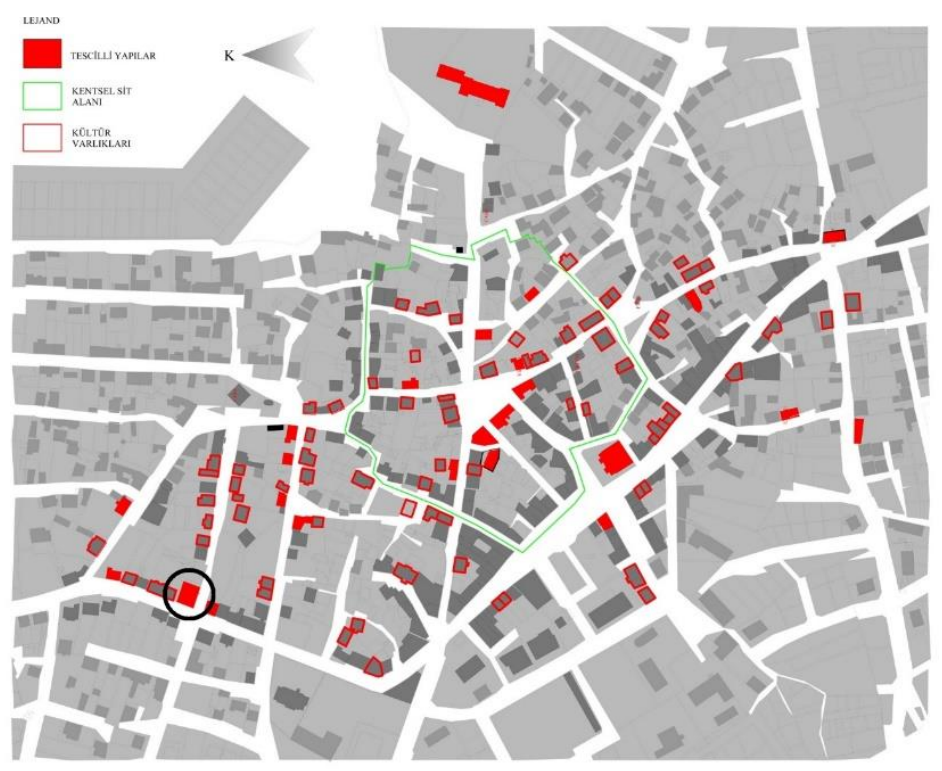

Şekil 2: Orhaneli’nin tescilli yapıları, kentsel sit alanı, kültür varlıkları ve Remzi Bey Konağı'nın konumu. 


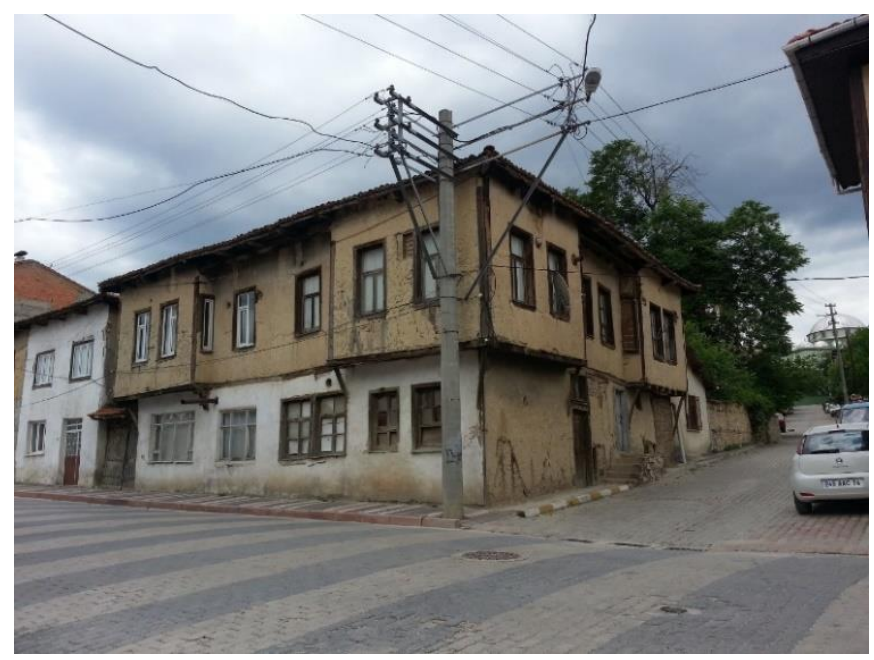

Şekil 3: Remzi Bey Konağ1 (Güneş Kaya Arşivi, 2016).

Remzi Bey Konağı'nın mülkiyeti hâlâ, inşa ettiren Remzi Bey'in ailesindedir. Zafer Caddesi ile Karakol Sokağı'nın kesişme noktasında yer alan yapının kuzey ve doğu cephelerini, kendi bahçesi ve bahçeye dahil yapı grubu çevrelemektedir. Remzi Bey Konağı'nın bahçesine, ana yapıdan sonra zaman içinde kalabalıklaşan ailenin barınma ihtiyacını karşılamak amacıyla, daha gösterişsiz üç yapı daha inşa edilmiştir. Caddenin diğer ucundaki 4 envanter numaralı yapı ile sonlanan geleneksel yapı sırasını, uyumsuz gabari ve cepheye sahip bir betonarme yapı kesintiye uğratmaktadır. Güneyinde kalan Karakol Sokağı'nın karşısında yine kendisi gibi tescilli bir sivil mimarlık örneği olan Hacı Bey Konağı bulunmaktadır (Şekil 4). Remzi Bey Konağı, 4 envanter numaralı yap1 ve 6 envanter numaralı Hacı Bey Konağı dışında, Zafer Caddesi ve Karakol Sokağı boyunca uzanan daha mütevazi geleneksel yapılar tescil kapsamı dışında bırakılmıştır (Şekil 5). Tescil edilen yapılar, çevrelerindeki diğer geleneksel yapılara göre biraz daha büyük ölçeklidir. Bu yazıda ele alınan yapının iki tarafinda uzanan yapı sırası, ardlarındaki avluları ile birlikte neredeyse bütün bir yap1 adası olarak korunmuş bir doku sergilemektedir.

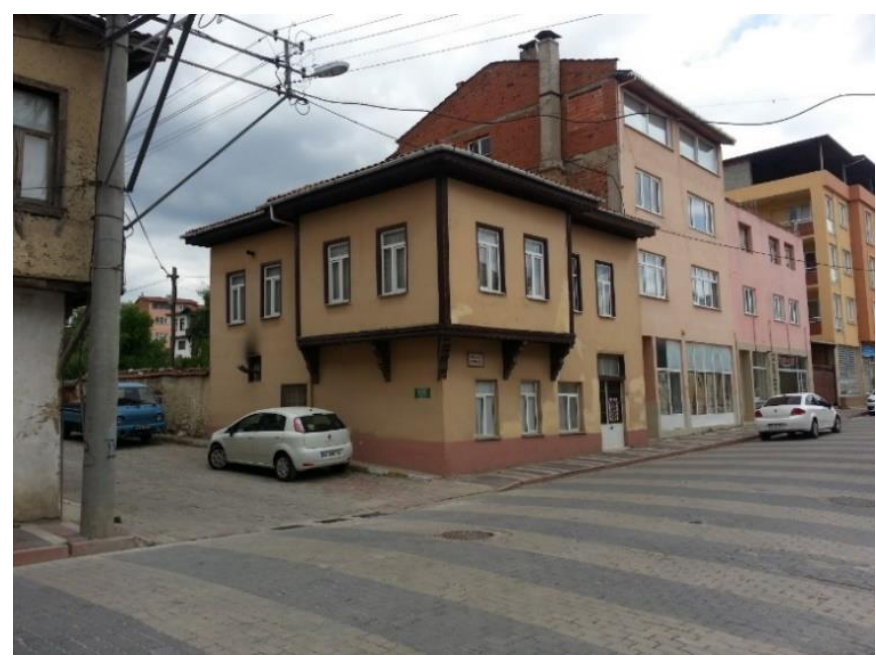

Şekil 4: Hacı Bey Konağı (Güneş Kaya Arşivi, 2016). 
Şekil 5: Zafer Caddesi silüeti (GTÜ Restorasyon Arşivi, 2016).

Yerel kişiler ile yapılan görüşmelerde konağın yerinde ticari işlevli "Remzi Bey'in Hanı"nın bulunduğu öğrenilmiştir (KK2). Yunan askerlerinin geri çekilirken neden olduğu yangında kullanılamaz hale gelen hanın yerine Remzi Bey, konağını inşa ettirmiştir. Zamanla ailenin genişlemesiyle birlikte parselin cadde yönüne sırayla konut işlevli üç yapı daha eklenmiştir ve son yap1 1950'li yıllarda tamamlanmıştır (Şekil 6). Günümüzde yapıların tamamı, Remzi Bey’in torunları tarafından kullanılarak yaşatılmaya çalışılmaktadır.

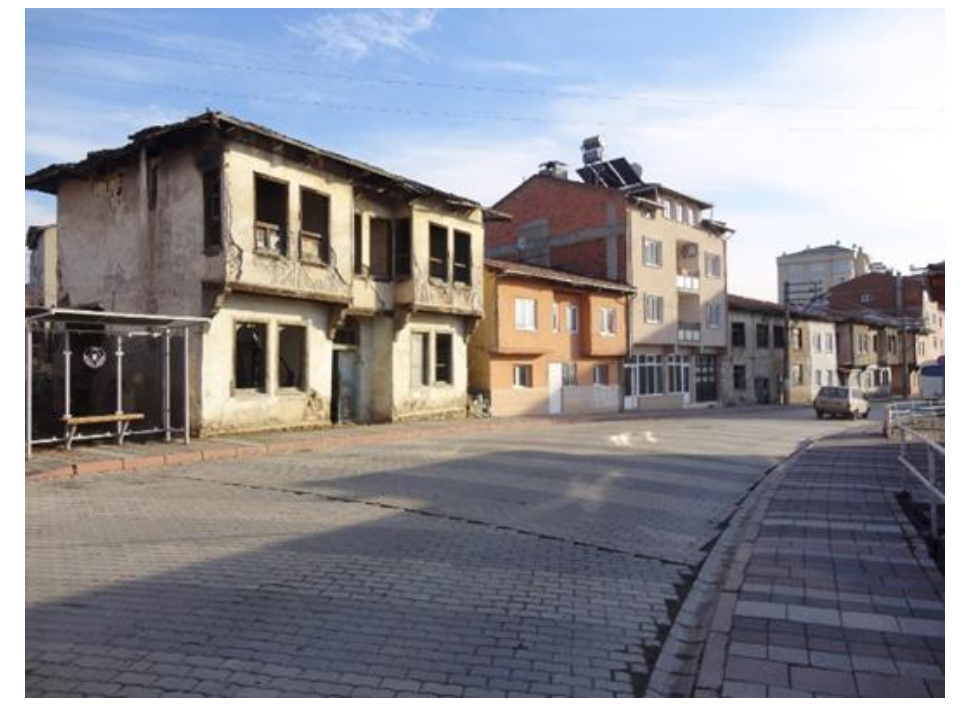

Şekil 6: Remzi Bey Konağı ve ek yapıları ile sonlanan yapı sırası (Güneş Kaya Arşivi, 2017).

\section{YAPININ PLAN, MALZEME VE YAPIM TEKNİĞİ ÖZELLİKLERİ (PLAN, MATERIALS AND CONSTRUCTION CHARACTRISTICS OF THE BUILDING)}

Remzi Bey Konağı, zemin ve birinci kat olmak üzere iki kattan oluşmaktadır. Kareye yakın dikdörtgen bir alan üzerinde, iç sofalı zemin kat planına sahiptir. Günümüzde iki ayrı kullanıcının mülkiyetinde olması nedeniyle iki girişi mevcuttur. Kullanıcılardan biri dönemsel olarak yapıyı yılın belirli zamanlarında kullanırken; yapının güney tarafında hayat yıl boyu kesintisiz sürmektedir. Güney bölümünün girişi güney cephesinden, Karakol Sokağı üzerinden sağlanmaktadır. İkincil giriş konağın kuzey cephesindedir. Parselde yapıya ait müştemilat, firın ve aileye ait diğer üç konut bulunmaktadır (Şekil 7). 


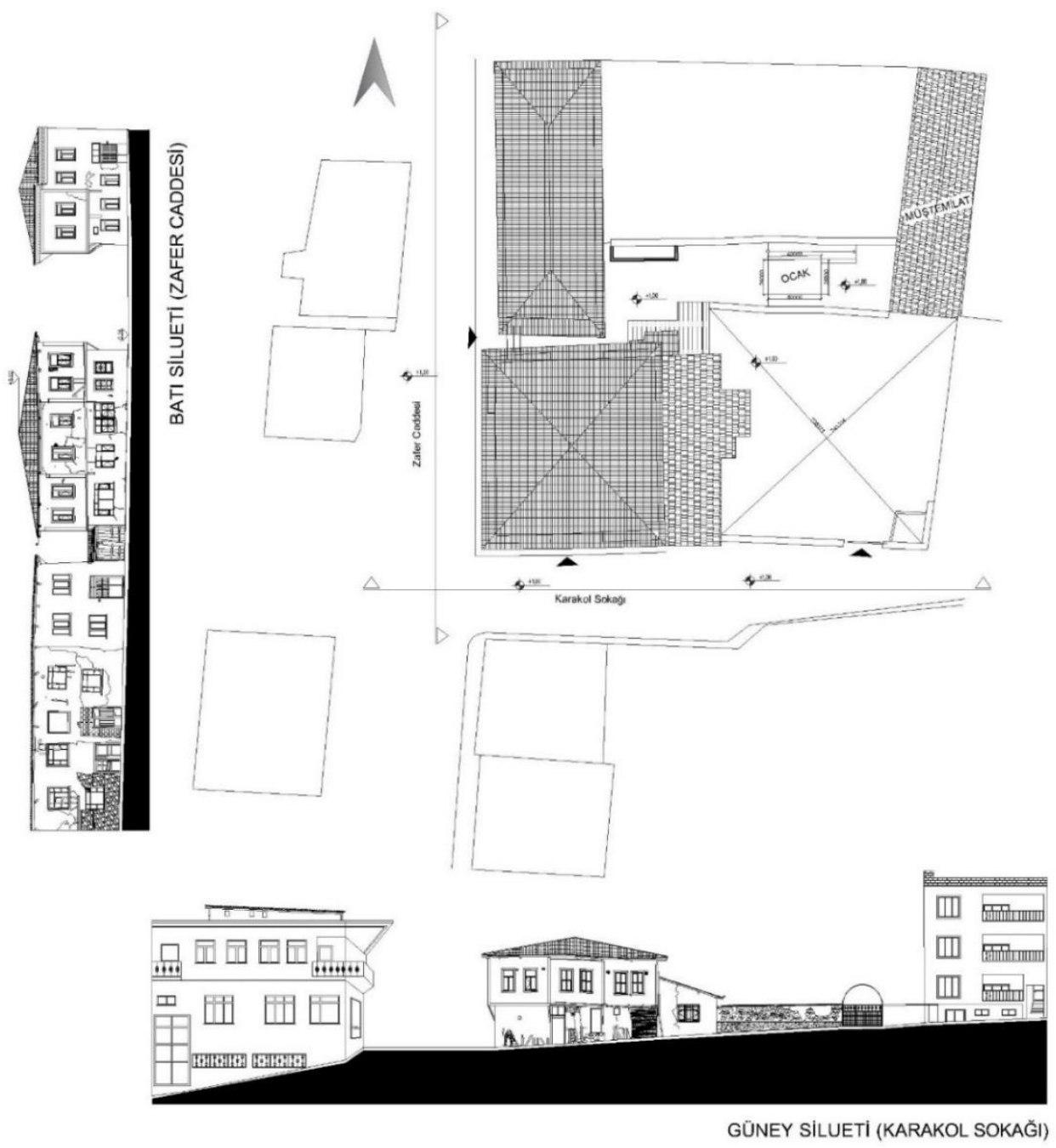

Şekil 7: Remzi Bey Konağ1 vaziyet planı ve sokak cepheleri (GTÜ Restorasyon Arşivi, 2016).

Remzi Bey Konağ1, biri köşe olmak üzere payandalarla desteklenen üç adet çıkmaya sahiptir. Aslında ana bir sofadan birimlere dağılan dört eyvanlı merkezi sofalı plan şemasına sahip yapı, sofanın ortasına doğu-batı doğrultusunda duvar eklenmesiyle bölünmüştür. Günümüzde güney ve kuzey bölümleri halinde iki ayrı konut birimi olarak kullanılmaktadır (Şekil 8). Güney kısmının zemin katına Karakol Sokağı'ndaki kapının solunda kalan girişten, birinci katına ise bu girişin sağındaki kapıdan dört basamak ile çıkılan sahanlıktan ulaşılmaktadır (Şekil 9). Kuzeydeki bölüme ise cadde üzerindeki bahçe girişinden önce bahçeye ardından yapıya ulaşılacak şekilde girilebilmektedir. Yapının inşa sürecinde ahır zemin katta değil, bahçede ayırı bir yapı olarak çözülmüştür. $\mathrm{Bu}$, ekonomik durumun iyi olmasının da bir göstergesidir. Aynı durum, mülkiyet sebebi ile ortasından bir duvar ile bölünmüş Efeler Evi için de geçerlidir (Şekil 10). Böylece tamamen konut işlevini yüklenen yapı, yalnızca subasman seviyesine kadar yerel kireçtaşı ile inşa edilmiştir. Üst yapı ahşap iskelet sistem arası kerpiç dolgu şeklinde tamamlanmış ve cephelerde kerpiç sıva kullanılmışır. Dört yöne eğimli kırma çatısı alaturka kiremit kaplıdır. Yapının bahçesinde yer alan kâgir firın da günümüzde hala aktif bir kullanıma sahiptir (Şekil 11). 

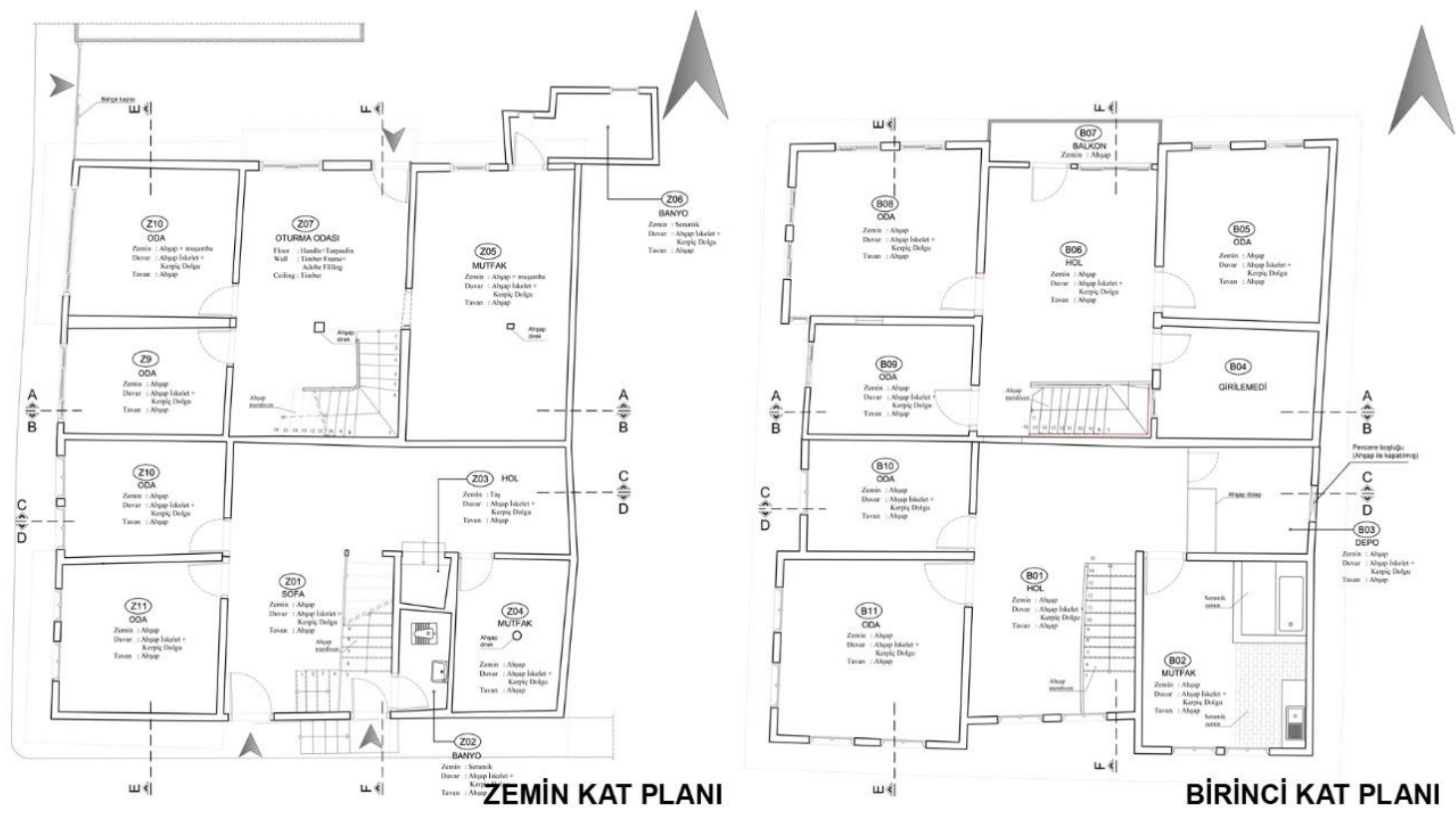

Şekil 8: Remzi Bey Konağı zemin kat ve birinci kat plan rölöveleri (GTÜ Restorasyon Arşivi, 2016).

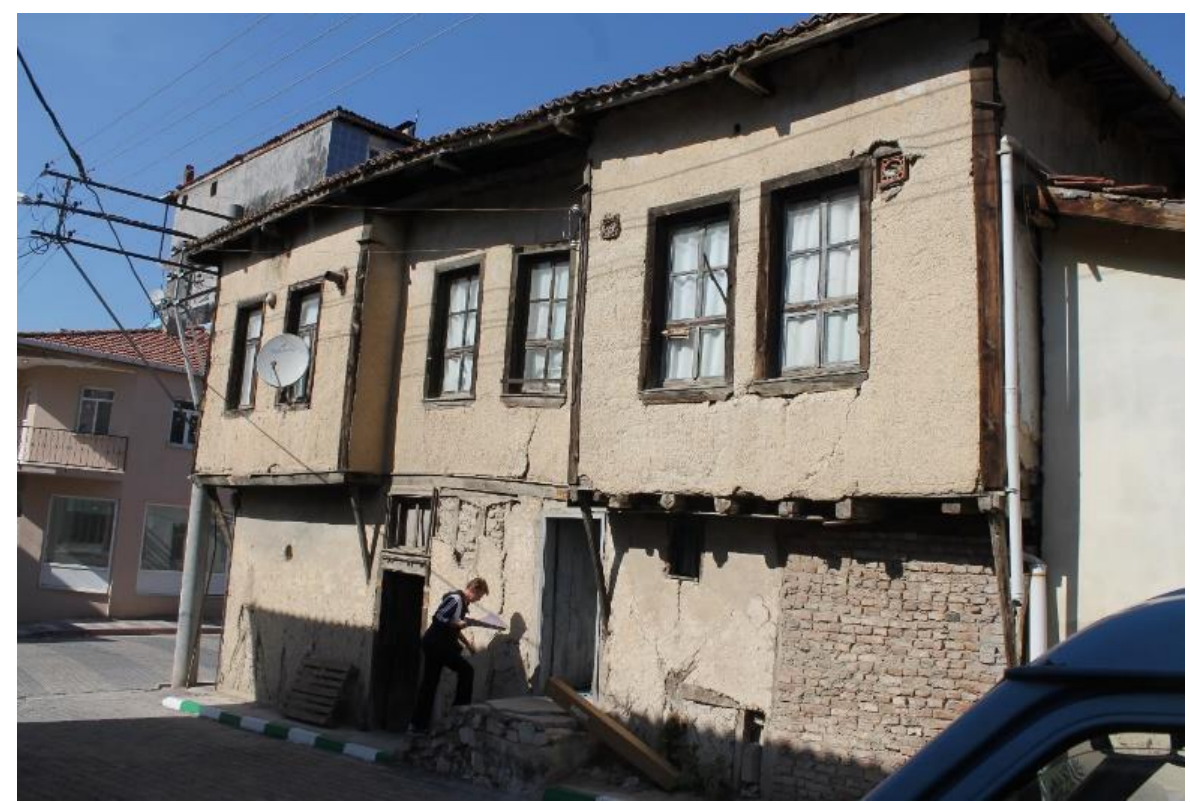

Şekil 9: Güney cephesinin Karakol Sokağı üzerindeki girişi (GTÜ Restorasyon Arşivi, 2016). 


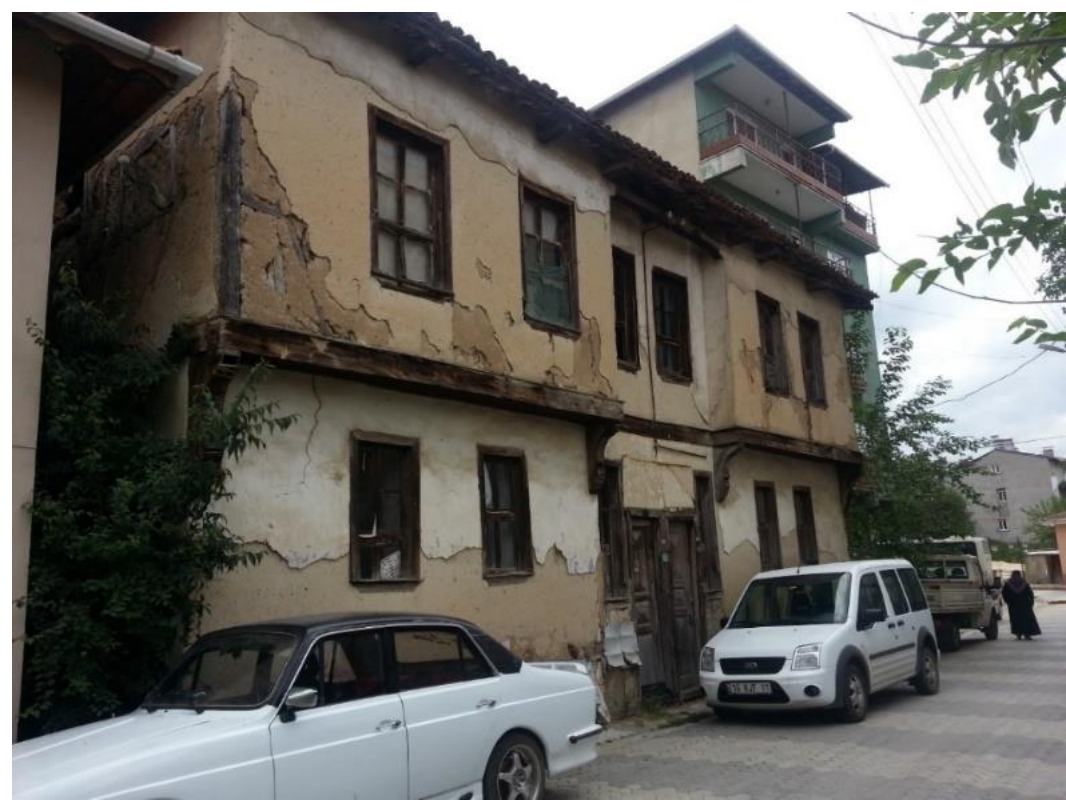

Şekil 10: Tescilli Efeler Evi (Güneş Kaya Arşivi, 2016)
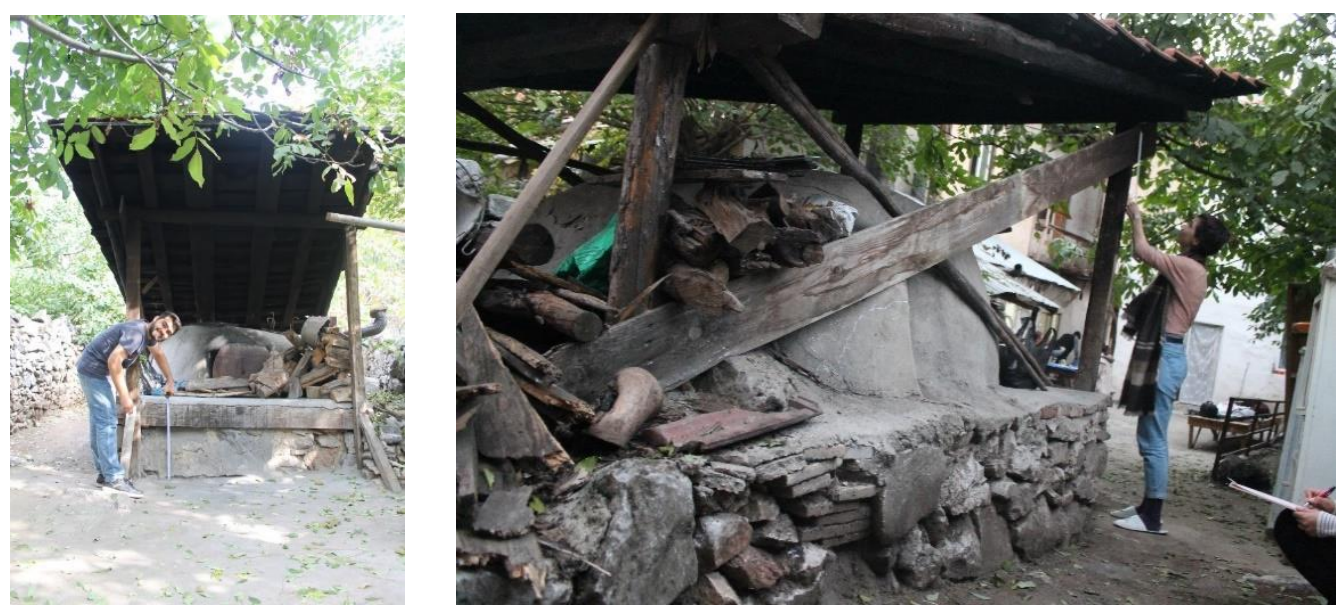

Şekil 11: Yapının bahçesindeki fırın (GTÜ Restorasyon Arşivi, 2016).

Yapının zemin katında, bir yüzlü iç sofalı ve "L" sofalı iki plan şemasından söz edilebilir. Her iki konutun ihtiyacını karşılamak üzere çağdaş malzemelerle eklenmiş ıslak hacimler de zemin katta yer almaktadır. Ayrıca özgün merdivenin (Şekil 12) yapının güney bölümünde kalmasından dolayı, yapının kuzey bölümünde düşey sirkülasyonu sağlayabilmek amacıyla ikinci bir ahşap merdiven eklenmiştir (Şekil 13). 


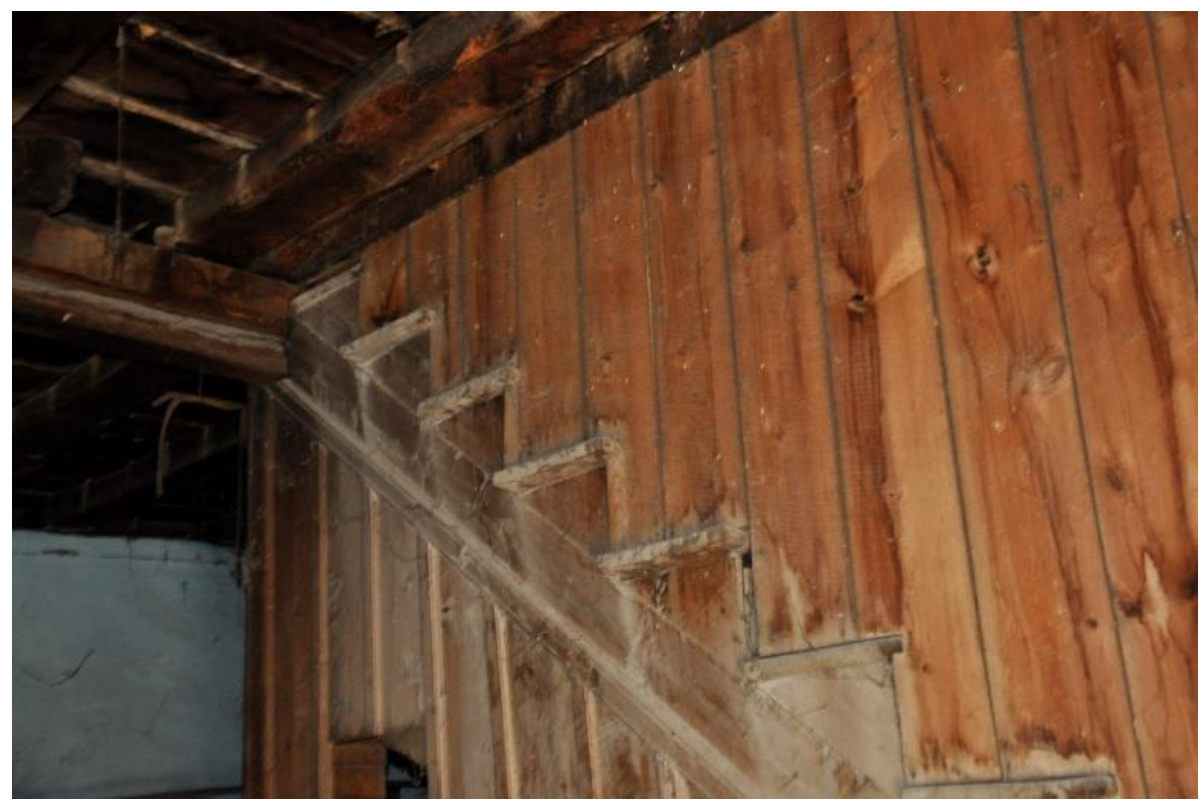

Şekil 12: Bölücü duvar içinde kalan özgün merdiven (GTÜ Restorasyon Arşivi, 2016).

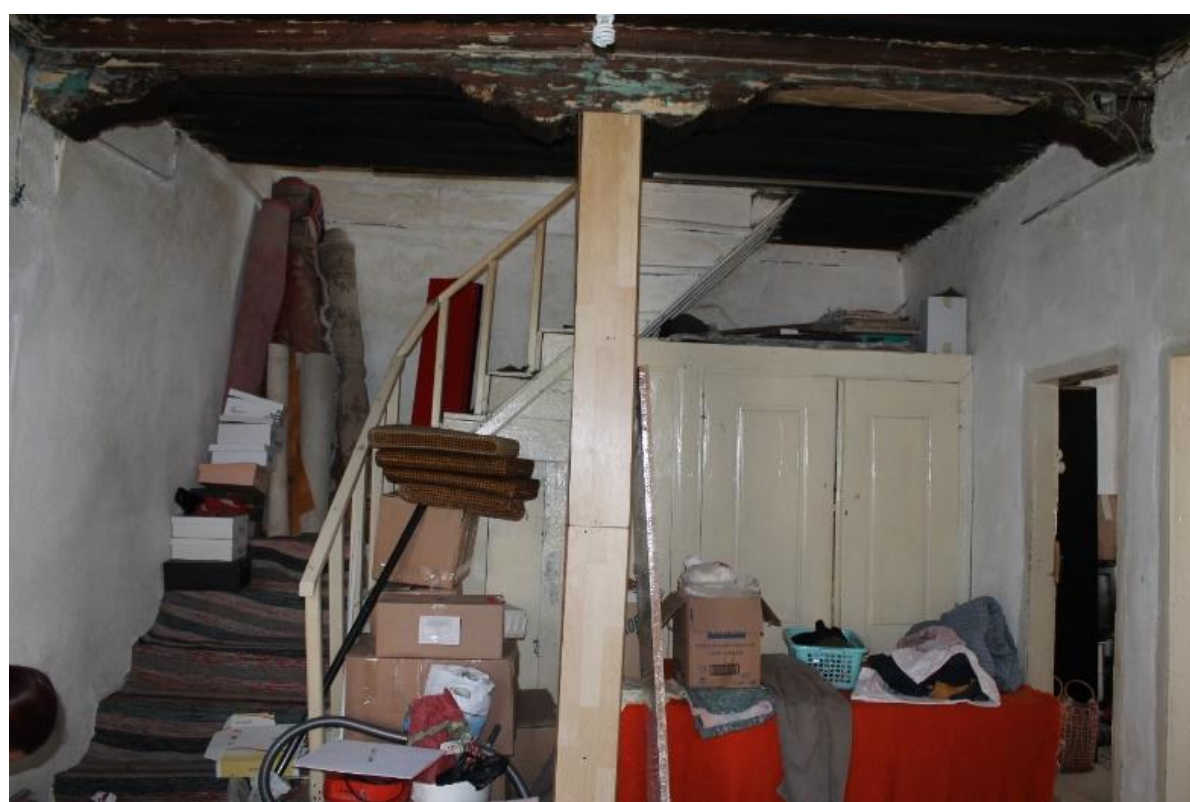

Şekil 13: Yapıya sonradan eklenen merdiven, 2016 (GTÜ Restorasyon Arşivi).

Birinci kat plan düzenlerinde sofaların iki yanında ikişer mekan ve kuzey sofasının ucunda geç dönem eki bir balkon yer almaktadır (Şekil 14). Balkonun ve balkona açılan kapının özgün olmadığ1 düşünülmüştür. Bu tahmin, kullanıcılar ile yapılan görüşmeler sırasında teyit edilmiştir (KK1). Orhaneli'deki balkonlu konutlarda balkon kapısının cephede simetrik şekilde düzenlendiğini gösteren örnekler ve Remzi Bey Konağı'nın balkon kapısının cepheye simetrik yerleşmemesi de bu bilgiyi desteklemektedir. (Şekil 15). 


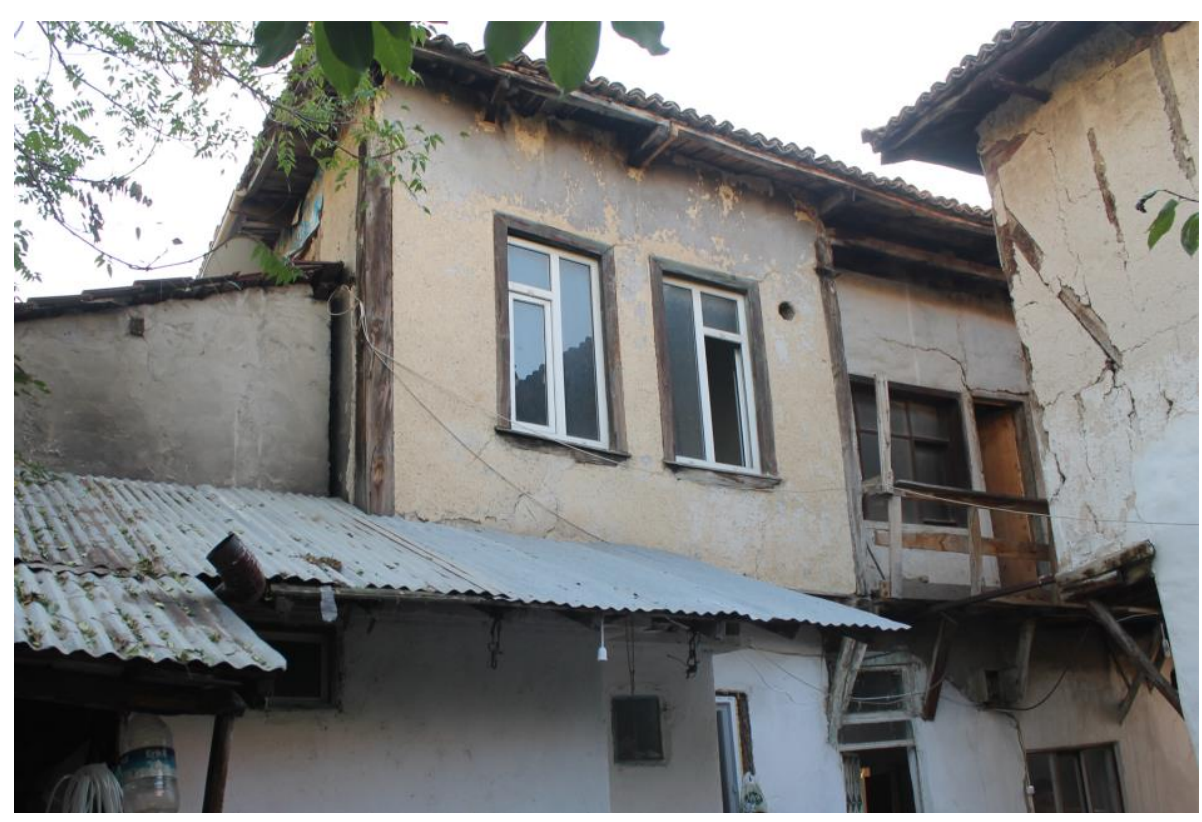

Şekil 14: Yapıya sonradan eklenen balkon, 2016 (GTÜ Restorasyon Arşivi).
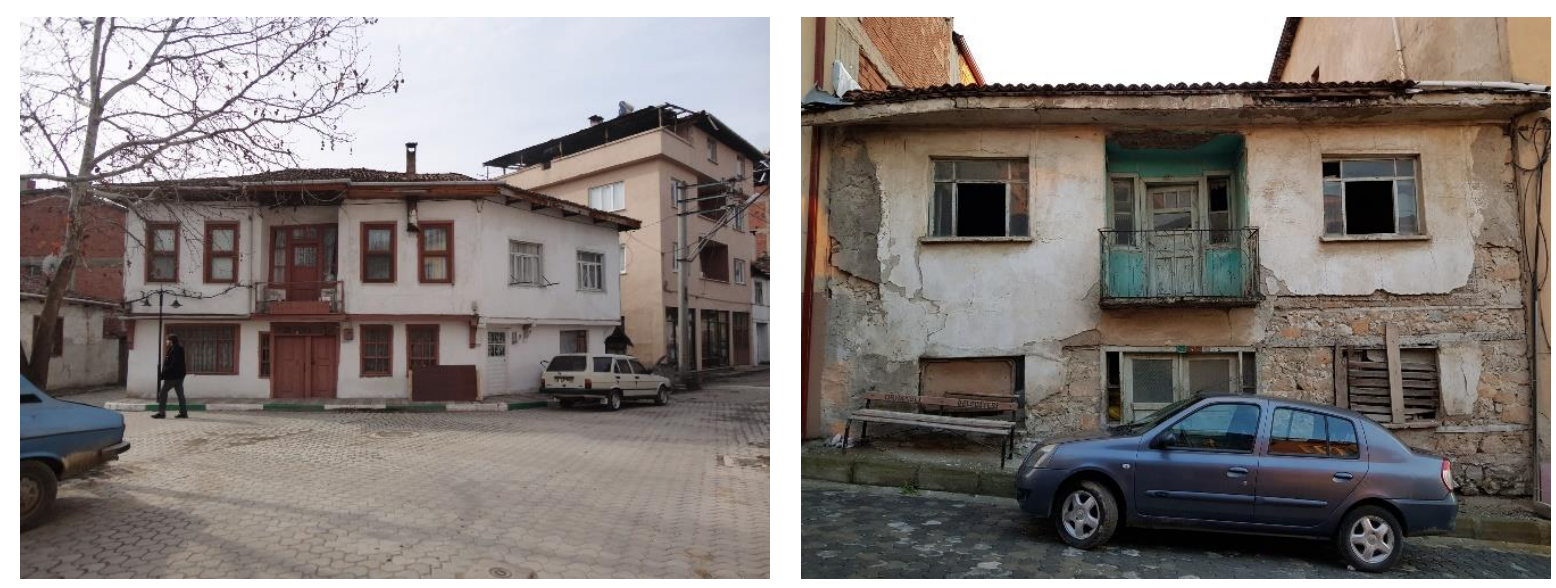

Şekil 15: Orhaneli’de balkonlu yapı örnekleri: Ümmet Ağa Evi (Güneş Kaya Arşivi, 2017) ve Ali Osman Gezgin Evi (Güneş Kaya Arşivi, 2019).

Birinci kat duvarlarının kerpiç dolgulu ahşap iskelet sistem olması nedeniyle odalarda, bir diğer geleneksel oda öğesi olan ocak yerleri bulunmamaktadır. Yerleşim genelindeki geleneksel konutlarda da ocaklar yalnızca yığma sistemli duvarlar içinde yer almaktadır.

Birinci katta yer alan tüm odaların tavanları geometrik desenlerle bezeli ve ahşap olup günümüzde yağlıboya ile boyanmıştır (Şekil 16). Yapıdaki bezemeli ahşap tavan silmelerine ve ahşap dikme başlıklarına karşın, diğer ahşap elemanların motifleri (dolap, yüklük, gusülhane kapakları vb) görece daha sade tercih edilmiştir. Ayrıca özgün detayların bezeme inceliklerine karşılık, yapıya sonradan eklenen veya özgün olmayan elemanların (ahşap korkuluk, kapı, pencere vb) da daha gösterişsiz, bezemesiz ve verniksiz kullanıldıkları gözlenmiştir. 

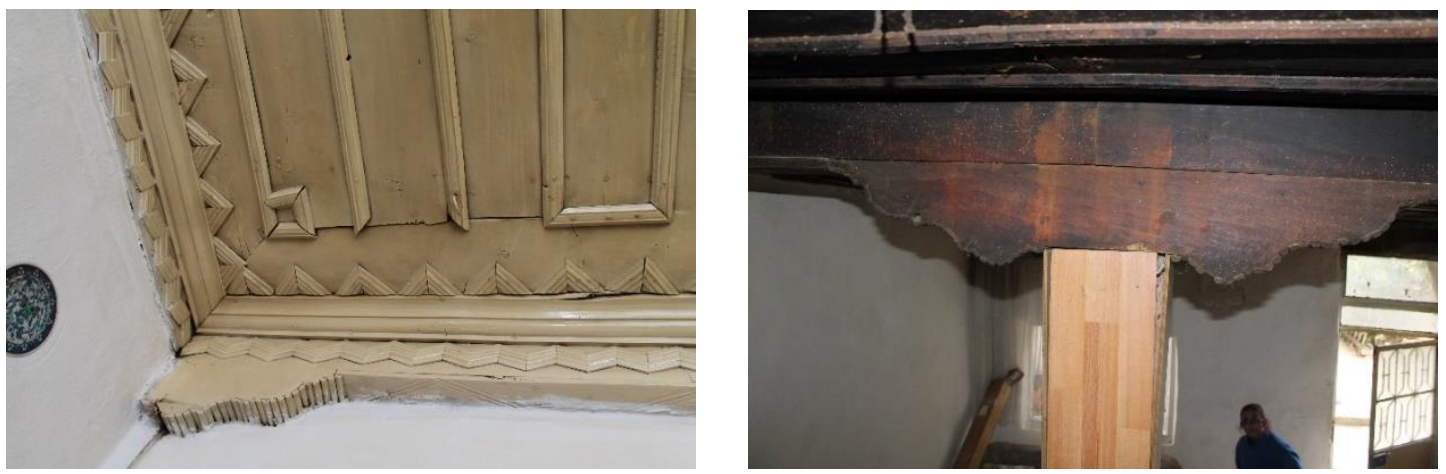

Şekil 16: Altında duvarın içinde kalan ahşap dikmenin başlığı ile birlikte tavan silmesi ve açıktaki ahşap başlıklara birer örnek (GTÜ Restorasyon Arşivi, 2016).

Remzi Bey Konağı'nın batı cephesinde mevcut olan oniki adet pencerenin üç tanesinin doğrama ve açıklıklarıyla tamamen özgün, iki pencerenin ise yapıya uyumlu şekilde yenilenen geç dönem doğraması olduğu tespit edilmiştir. Değişen pencerelerden bir kısmı daha geniş ahşap doğramalarla, bir kısmı da özgün açıklığa pvc pencereler yerleştirilmek suretiyle farklı zamanlarda yenilenmiştir. Orta aks pencelerinin, yapı ikiye bölündükten sonra çift kanatlı ana giriş kapısının kapatılmasının ardından açıldığı düşünülmektedir (Şekil 17). Yapının Karakol Sokağa bakan güney cephesinde görülen yedi adet pencerenin ise birinci katta yer alan altı tanesi deformasyona uğramalarına rağmen özgün olup, zemin kattaki geç döneme ait küçük pencere, ihtiyaç nedeniyle eklenen sslak hacim için açılmıstır (Şekil 9).

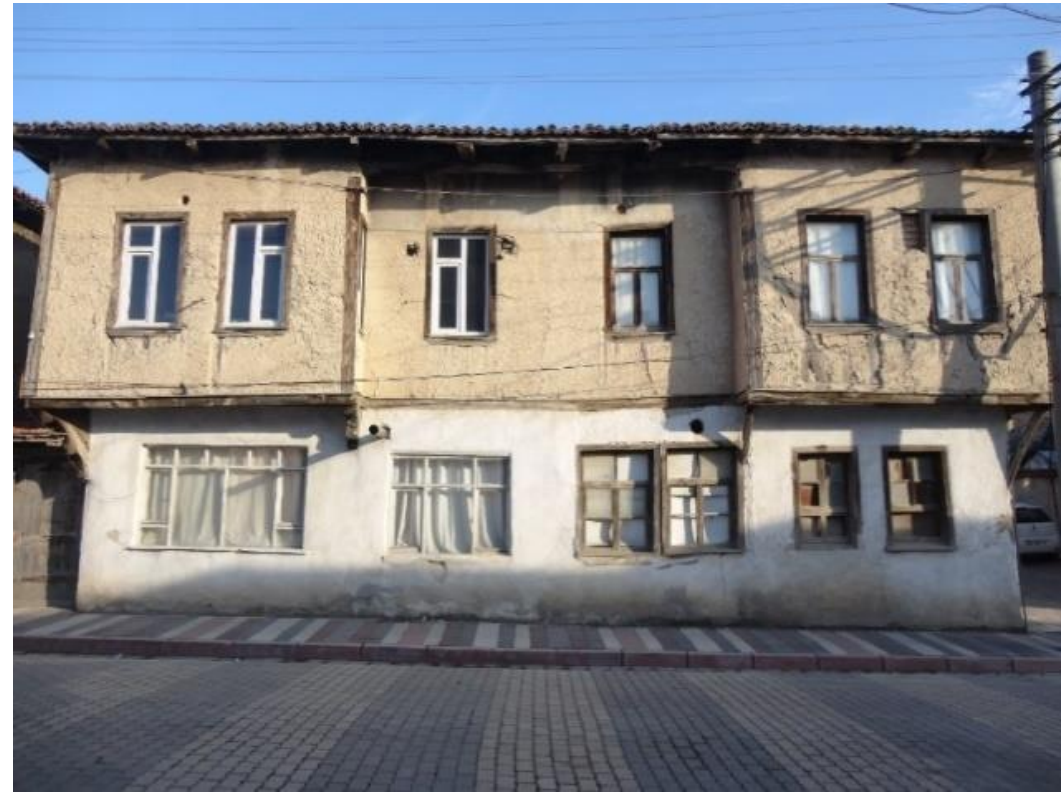

Şekil 17: Remzi Bey Konağı'nın batı cephesi (Güneş Kaya Arşivi, 2017).

Yapının bahçeye bakan kuzey cephesinde görülen dokuz pencereden dört tanesi özgündür. Pencerelerin bir kısmı yine plan şemasındaki değişiklikler nedeniyle açılırken, bir kısmı da cadde cephesindeki gibi mevcut açıklığa yeni doğrama yerleştirilerek yenilenmiştir. Geç dönem eki olan 
balkon da kuzey cephesinde yer alıp (Şekil 14), balkon kapısı mevcut pencerenin kapıya çevrilmesi ile açılmışır (KK2). Arka bahçeye bakan doğu cephesine ise, tek katlı betonarme bir ek, yap1 boyunca uzanacak şekilde inşa edilmiştir (Şekil 18, Şekil 21).

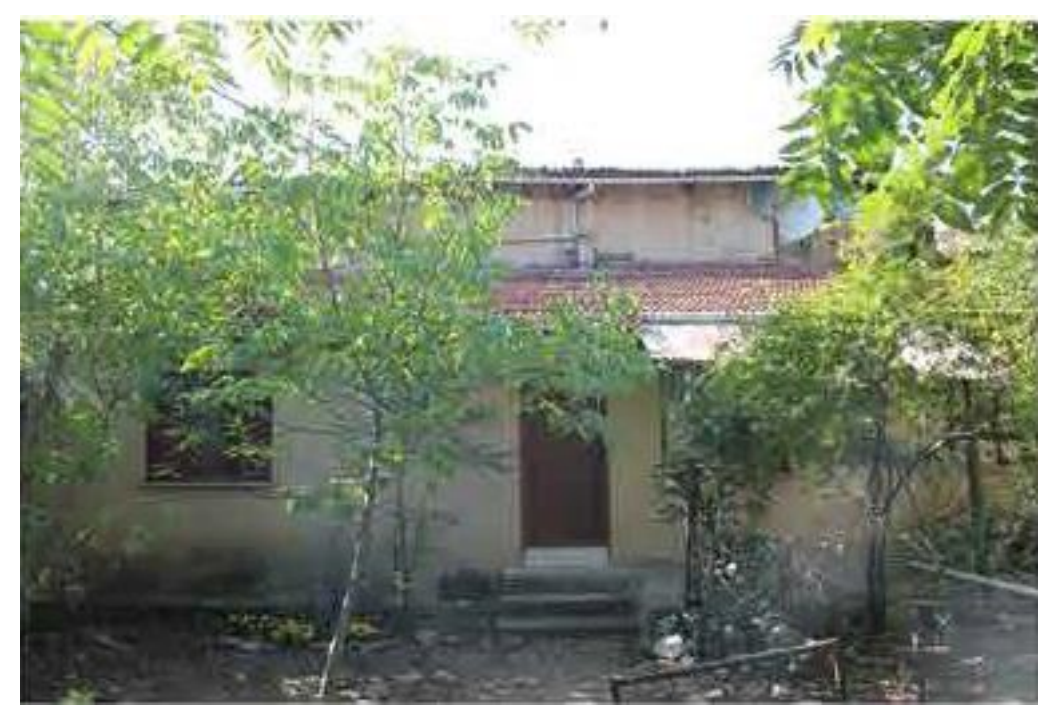

Şekil 18: Yapının doğu cephesini kaplayan tek katlı betonarme ek yapı (GTÜ Restorasyon Arşivi, 2016).

\section{YAPININ GEÇİRDİĞİ DEĞİŞİMLER (ALTERATIONS OF THE BUILDING)}

Remzi Bey Konağı'nın geçirdiği değişimlerin tespiti ve restitüsyonunun geliştirilmesi için kullanıcı ile konak hakkında detaylı görüşmeler gerçekleştirilmiş, yapıda gerekli ölçümler ve fotoğraflamalar yapılmıştır. Yürütülen kapsamlı belgeleme çalışmasının ardından görülen en önemli değişim, mülkiyet nedeniyle ortasından doğu batı doğrultusunda örülen bir duvarla ikiye ayrılmasıdır. Yapıda, geçirdiği radikal müdahalelerin yanı sıra düzensiz aralıklarla basit onarım kapsamında tadilatlar yapilmaktadir.

Kullanıcı ile yapılan görüşmeler (KK1) ve tespit edilen izler (Şekil 16, Şekil 20) sayesinde özgün yapının her iki katta da dört eyvanlı merkezi sofalı plan şemasına sahip olduğu anlaşılmıştır (Şekil 19) (GTÜ, 2016-2017). Özgün plan şemasında odalar; merkezi sofa etrafına, aralarında eyvanlar bırakılarak köşelere yerleşmekte; cadde ile sokağa bakan üç köşe oda çıkma yapmakta ve zemin kattaki mutfak dışındaki ıslak hacimler özgün şemada yer almamaktadır (Şekil 8, Şekil 19, Şekil 21, Şekil $22-J)$.

\footnotetext{
* Bu çalışmanın kapsamı için yeterli olduğu düşünülerek sunulan veriler dışında kalan; Remzi Bey Konağı'nın rölöve-restitüsyon çizimleri ile raporlarına, analojik değerlendirmelerine ve süreçte elde edilen daha fazla bilgiye, GTÜ Mimarlık Fakültesi Restorasyon Arşivi (2016-2017)'nden erişilebilir.
} 

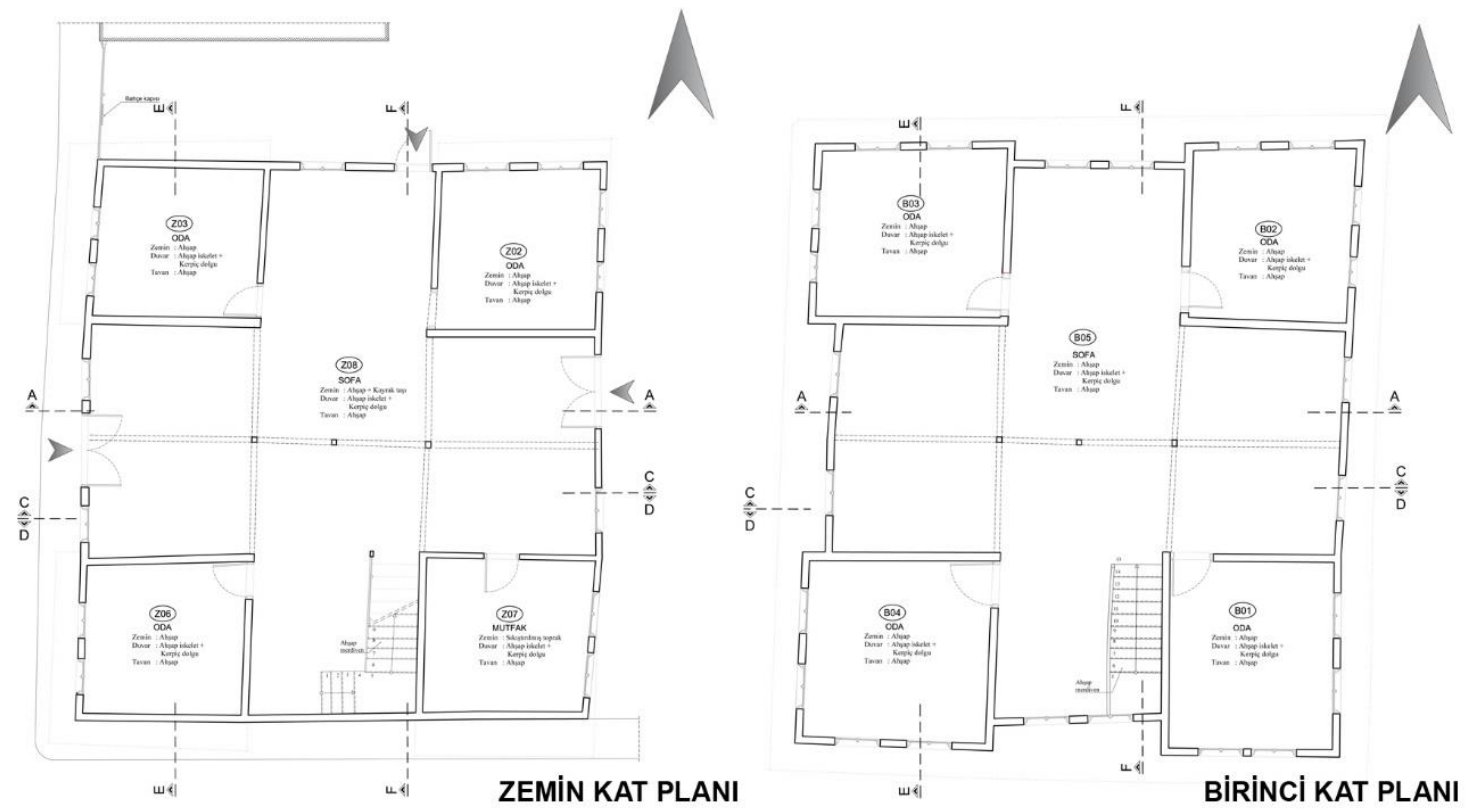

Şekil 19: Remzi Bey Konağı zemin kat ve birinci kat plan restitüsyonları (GTÜ Restorasyon Arşivi, 2016).

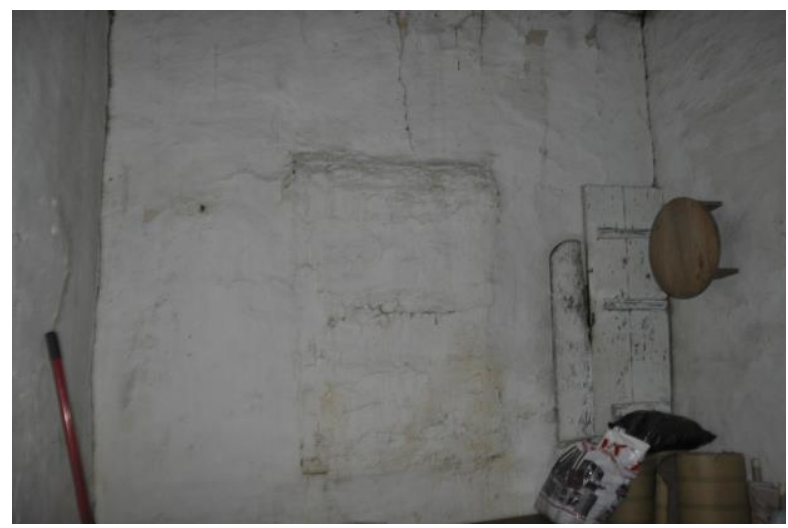

Şekil 20: Yapının kapatılmıs pencerelerinden birinin izi (GTÜ Restorasyon Arşivi, 2016). 


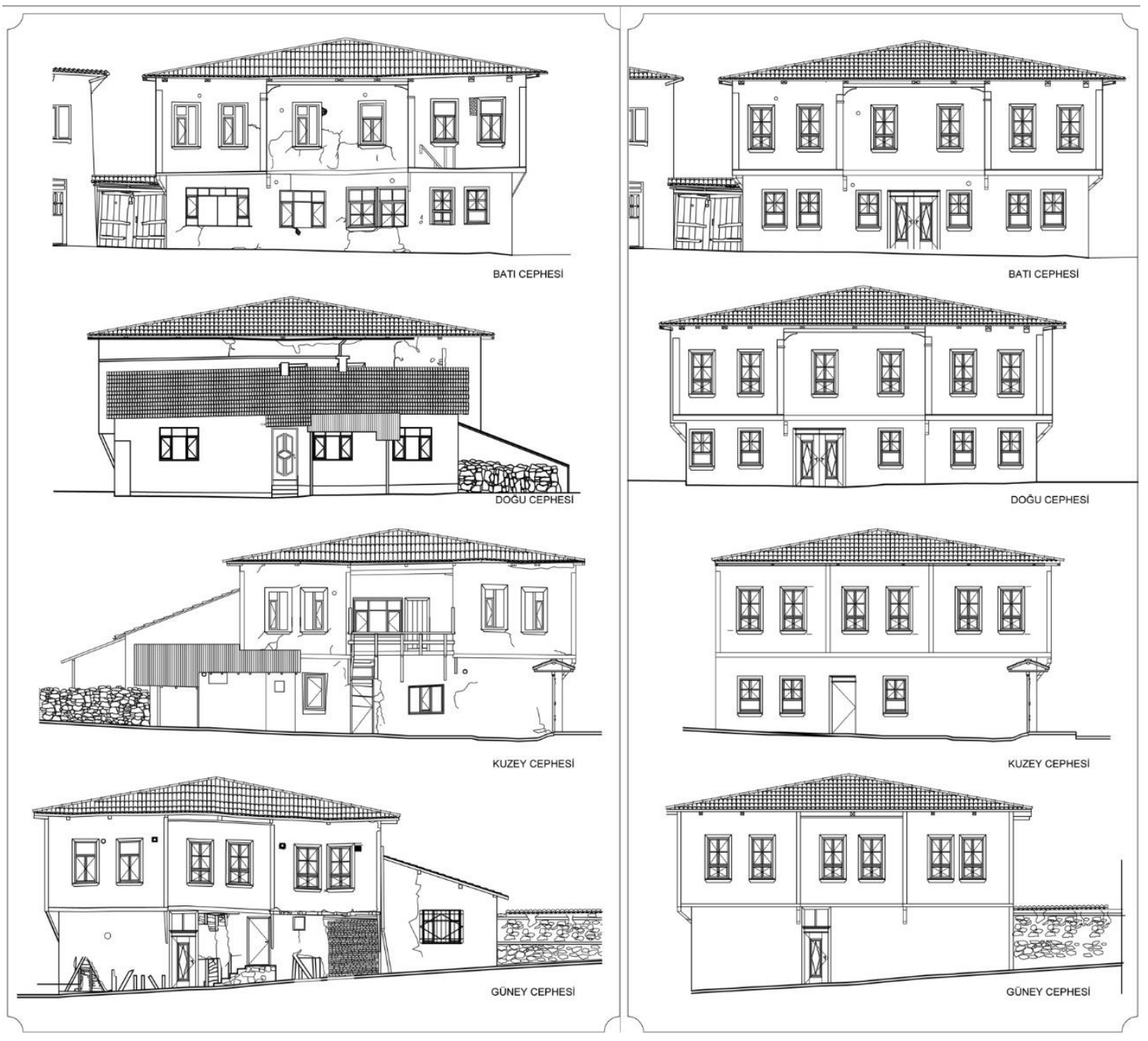

Şekil 21: Remzi Bey Konağ1 cephe rölöveleri ve restitüsyonları (GTÜ Restorasyon Arşivi, 2016).

Zemin kat planında görülen en önemli değişiklik, yapının bölünen dört eyvanlı merkezi sofasıdır (Şekil 23 - A). Bu özgün dört eyvanlı plan şeması, yerleşim genelinde nadir rastlanan bir düzendir (Şekil 22, Şekil 24). Yapıyı ikiye ayıran duvara entegre ahşap merdivenin geç dönem eki olduğu, özgün sofa şeması incelendiğinde anlaşılmaktadır (Şekil 22 - C). Yapının taşlık ve sofasında izleri görülebilen ancak günümüzde duvar içinde kalmış ahşap dikmeler, bezemeli başliklara sahiptir. Yapının özgün ana girişinin cadde cephesinden sağlandığı düşünülmektedir (Şekil 22 - D). Özgün halde, ana giriş ile aynı aksta yer alan ve ahşap çift kanatlı bir kapı olduğu tahmin edilen bahçeye çıkış kapıs1 günümüzde mevcut değildir (Şekil 22 - E). Günümüzde bahçeye çıkışı sağlayan kapı, yapının ikiye bölünmesinin ardından açılmıştır.

Birinci kattaki merkezi sofanın, ölçümler ve izler sonucu (GTÜ, 2016-2017) zemin kattaki merkezi planlı sofa ile çakıştığı görülmüştür (Şekil 22 - B, Şekil 23 - A). Ancak sofanın bu gösterişli şeması, yine yapının ikiye bölünme sürecinde değişmiştir. Duvar içinde kalan kirişlerde, dikmelerin üzerindeki bezemeli ahşap yastıklar okunabilmektedir (Şekil 13, Şekil 16). Geç dönemde örülen bu bölücü duvara bitişik depo ve oda olarak kullanılan iki küçük mekan da, özgün plan şemasında sofanın eyvanlarının birer parçasıdır (Şekil 22 - F, Şekil 23 - F). Birinci katta mutfak olarak kullanılan 
mekanın özgün tasarımda, tüm tamamlayıcı öğeleriyle geleneksel bir oda olduğu düşünülmüş, kullanıcıyla yapılan birebir görüşme sonucunda da öğrenilmiştir (Şekil 23 - G) (GTÜ Restorasyon Arşivi).
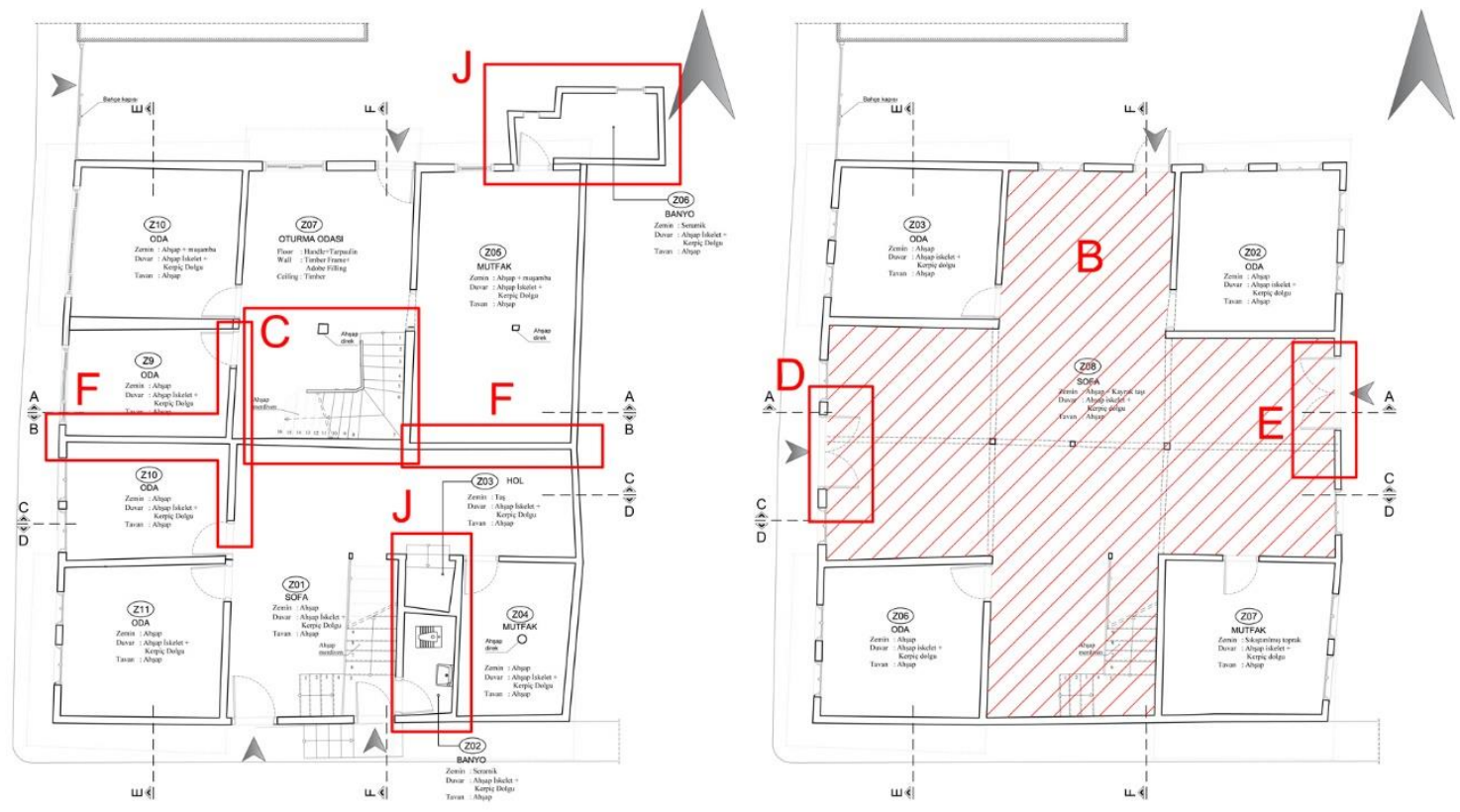

Şekil 22: Remzi Bey Konağı'ndaki değişimlerin zemin kat rölöve ve restitüsyon planları üzerinde gösterimi (GTÜ Restorasyon Arşivi, 2017).

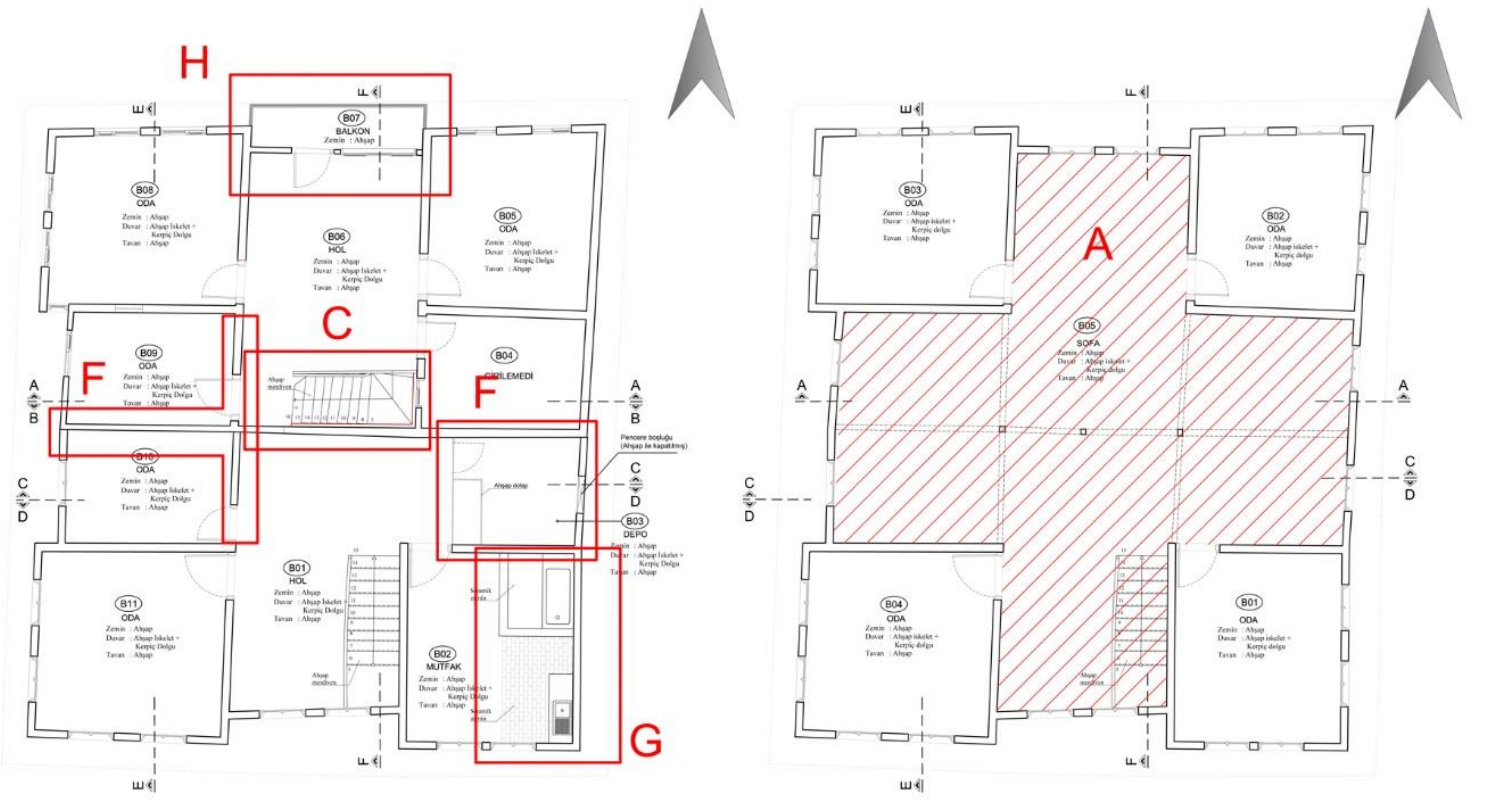

Şekil 23: Remzi Bey Konağı'ndaki değişimlerin birinci kat rölöve ve restitüsyon planları üzerinde gösterimi (GTÜ Restorasyon Arşivi, 2017). 
Özgün kap1 ile pencere doğrama ve kanatları ahşaptır. Pencere kanatları zaman içinde kısmen değiştirilmiş ve yer yer pvc doğramalar yerleştirilmiş olsa da, yapının özgün diş pencere doğramaları yerlerinde korunmuş haldedir (Şekil 21, Şekil 24). Yapıya erişimi sağlayan özgün dış kapıların ise, yerleşim genelindeki analojiler, kullanıcı ile görüşmeler ve şema incelemeleri sonucu konumları belirlenebilmiştir (Şekil 25).
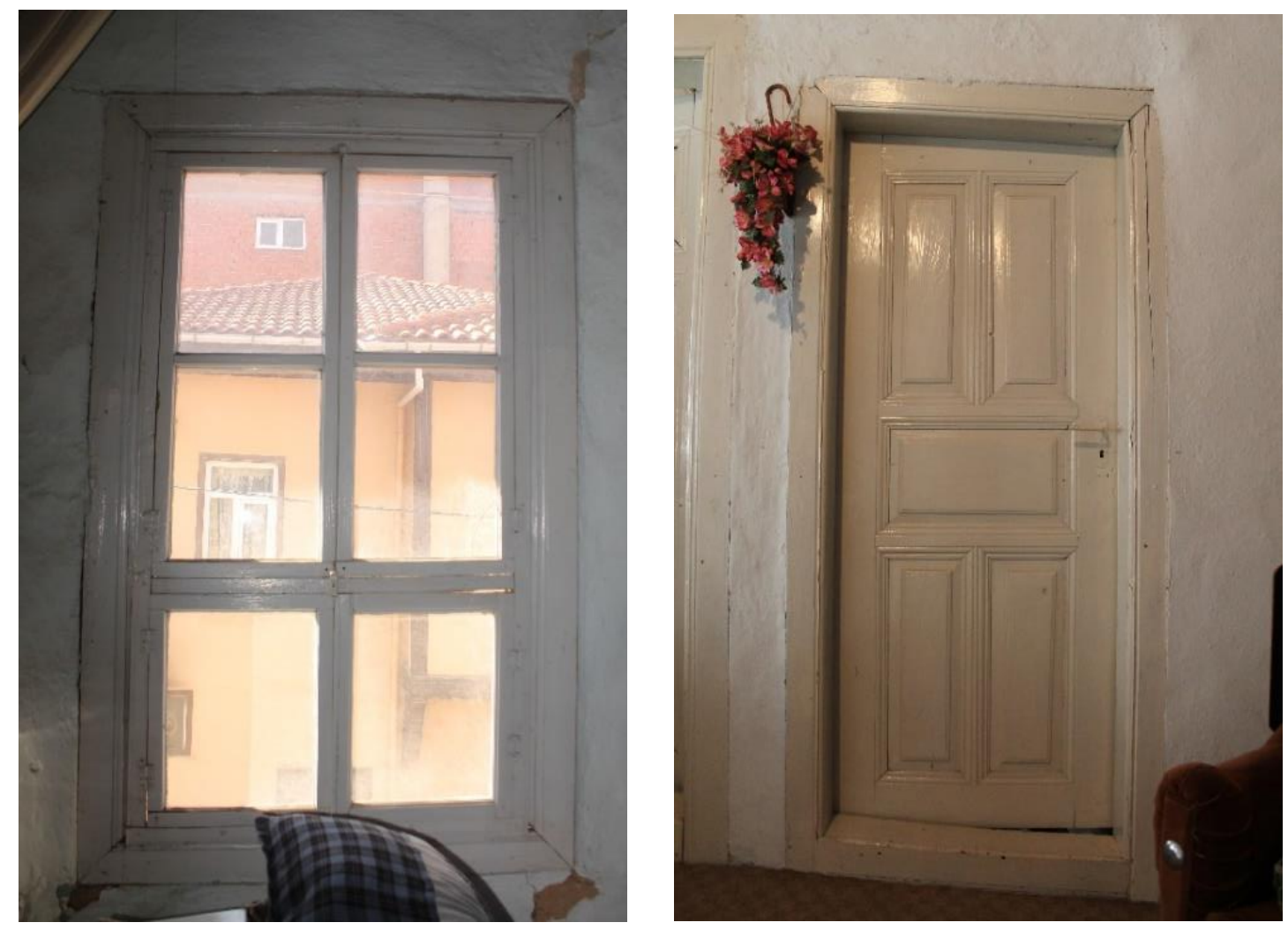

Şekil 24: Remzi Bey Konağı'nın özgün iç kapı ve pencere doğrama örnekleri (GTÜ Restorasyon Arşivi, 2016).

Yapıdaki izlerin yanı sıra Orhaneli'deki geleneksel yapılar ile karşılaştırmalı çalışma yapıldı̆̆ında da bahsedilen şekilde bir cephe ve plan düzenine ulaşılmaktadır (Şekil 25). GTÜ Mimarlık Fakültesi tarafından Remzi Bey Konağı ile benzer bir yöntem izlenerek belgelenen konutlardan analojik veriler elde edilebilmektedir. Yerleşimde yer alan ve söz konusu yapıdan daha eski tarihli Pekmezciler Evi (Güneş, 2018), avlusunda çeşitli dönemlere ait müştemilatları ve cadde üzerindeki ana konut yapısı ile şema ve cephe düzeni açısından benzerlikler göstermektedir. Remzi Bey Konağı'ndan daha küçük boyutlu bir yapı olduğundan dolayı yerleşim genelinde sık rastlanan plan tiplerinden olan birinci katta bir eyvanlı iç sofalı veya "L" sofalı olarak adlandırlabilecek plan düzenindedir (Eldem, 1954: s.114-126) (Şekil 26, Şekil 27). Ç1kmalı ve simetrik bir cephe düzenine sahiptir. İnşasından günümüze değişimler geçirmesine rağmen, yapılan müdahaleler konut üzerinde okunabilmektedir (Güneş, 2018). 


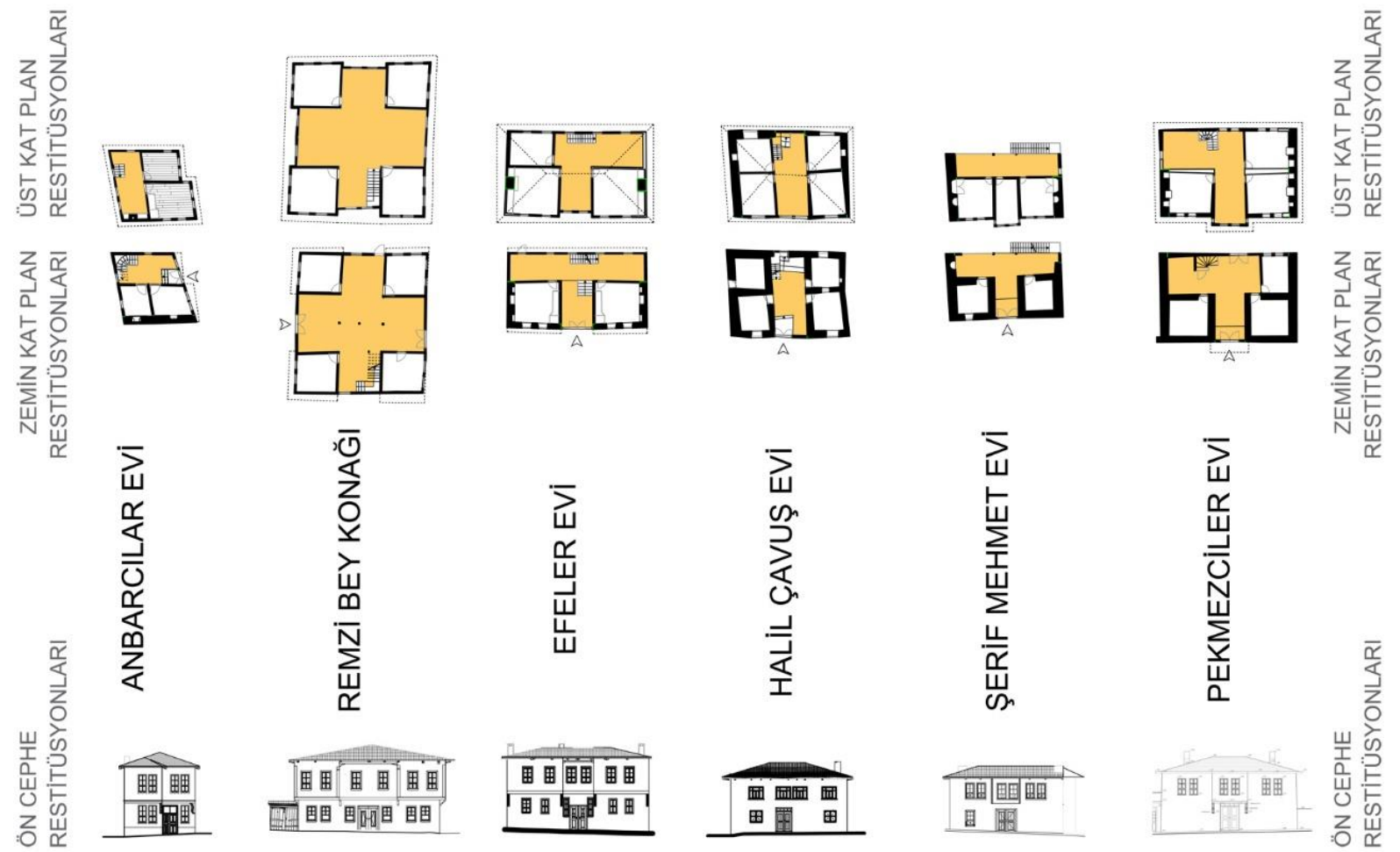

Şekil 25: Orhaneli geleneksel yapıları plan ve cephe restitüsyon örnekleri (GTÜ Restorasyon Arşivi, 20162018).

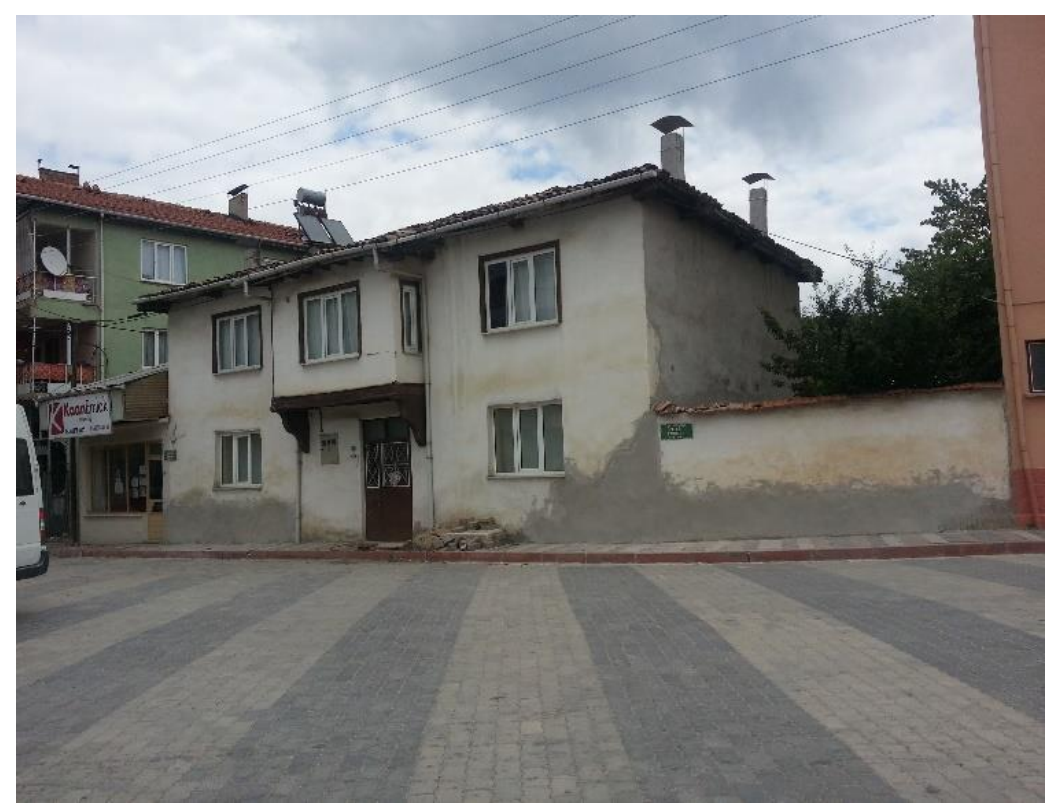

Şekil 26: Pekmezciler Evi (kişisel arşiv, 2016). 

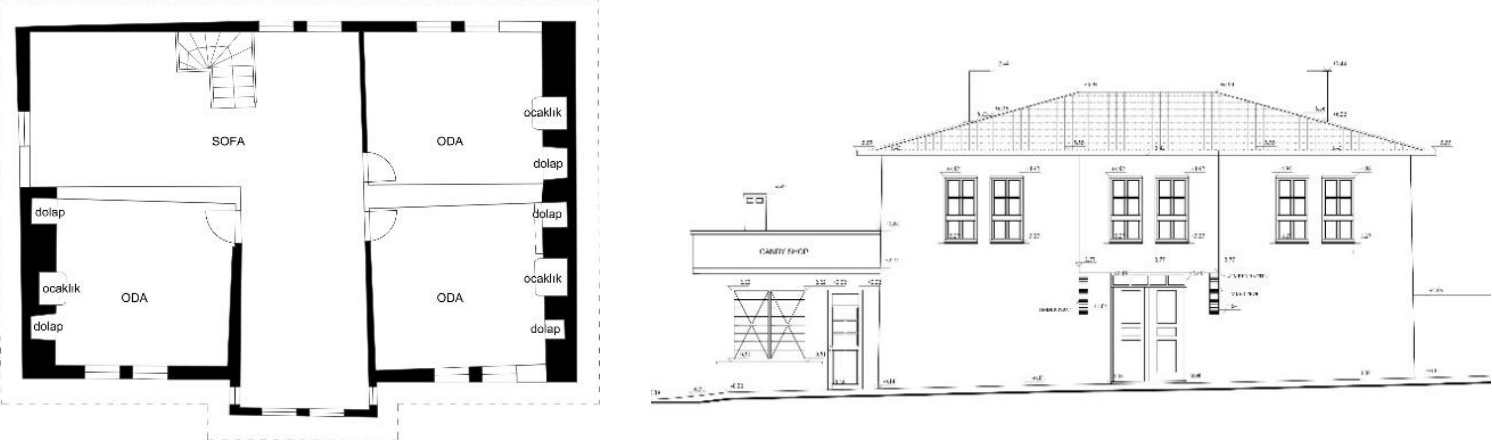

Şekil 27: Pekmezciler Evi birinci kat planı ve ana cephe restitüsyonu (GTÜ Restorasyon Arşivi, 2016).

Yine Orhaneli'de yer alan ve analoji için yararlanılan yapılardan biri de Efeler Evi'dir. Plan şeması, mekanların yerleşimi, kullanımı ve sirkülasyonu ile Remzi Bey Konağı'na benzerlik göstermektedir. Efeler Evi'nin malzeme kullanımı, Pekmezciler Evi’nden farklı olarak, Remzi Bey Konağı ile daha benzerdir. Barındırdığ1 özgün kapı ve pencereleri de bezemeleri, malzemeleri ve kullanımları ile örnek teşkil etmektedir (Şekil 11, Şekil 28). Ayrıca Efeler Evi, ortadan bir duvar ile ikiye bölünmesinin ardından plan ve cephe düzenini okunamaz hale getirecek değişimler geçirmemiştir. Bu sayede cephe düzeni ve değişim süreci ile ilgili de analojik olarak daha güvenilir bilgiler elde edilebilmiştir.
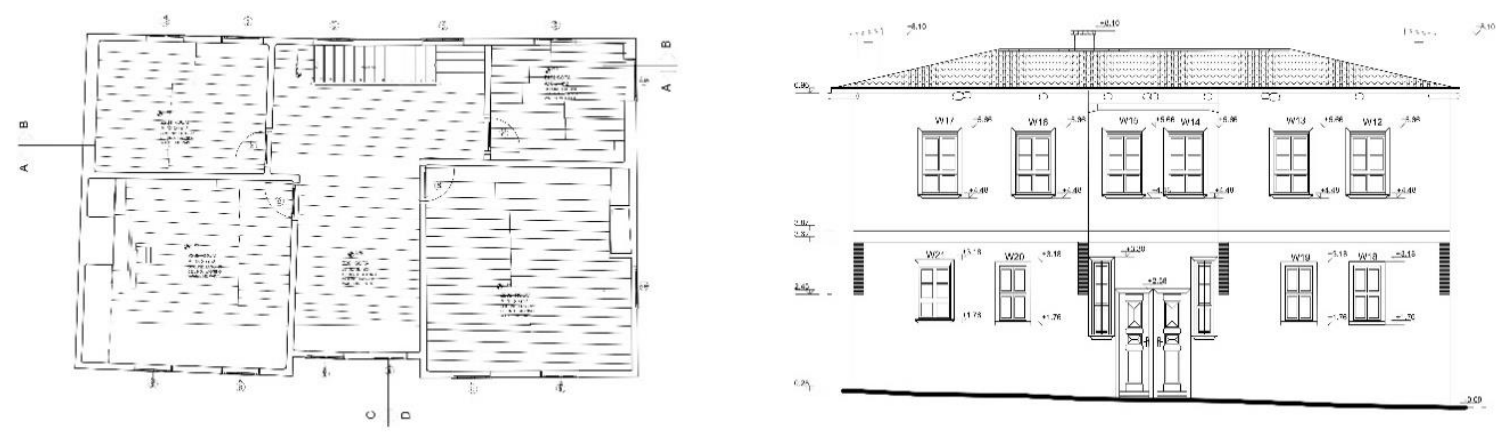

Şekil 28: Efeler Evi birinci kat planı ve cephe restitüsyonları (GTÜ Restorasyon Arşivi, 2016).

\section{YAPI VE YERLEŞİM ÖLÇEĞİNDE KORUMA SORUNLARI (CONSERVATION PROBLEMS IN BUILDING AND SETTLEMENT SCALE)}

Remzi Bey Konağı, köşesinde yer aldığı cadde ve sokak boyunca uzanan bir grup geleneksel yap1 ile birlikte yerele özgü bir dokuyu temsil etmektedir. Söz konusu tescilli yapılar ile tarihi dokunun yanlarında ve karşılarında betonarme yapılar yükselmiştir (Şekil 29). İmar planlarının izin verdiği şekilde, yalnızca yerleşimin bu bölümünde değil yerleşim genelinde yapı sıralarındaki tarihi yapılar yılkılarak yerlerine günümüz yapıları inşa edilmiştir. Böylece Orhaneli'de yerel malzemelerin kullanıldığı geleneksel yapım sistemleriyle inşa edilen konut dokusu yakın zamanlarda tahrip edilmiş 
ve yerlerini niteliksiz apartmanlara bırakarak kaybolmuştur. Yakın tarihlerde dokuda bozulmaların arttı̆̆1 görülmektedir. İlçeye bağl1 köylerde (örneğin tescilli Deliballılar Köyü (Güneş, 2015.), Ağaçhisar Köyü, Çınarcık Köyü vd) bütüne yakın korunabilmiş bir geleneksel dokudan bahsedilebilirken ilçe merkezinde artık ancak geleneksel dokunun izlerinden bahsedilebilmektedir.

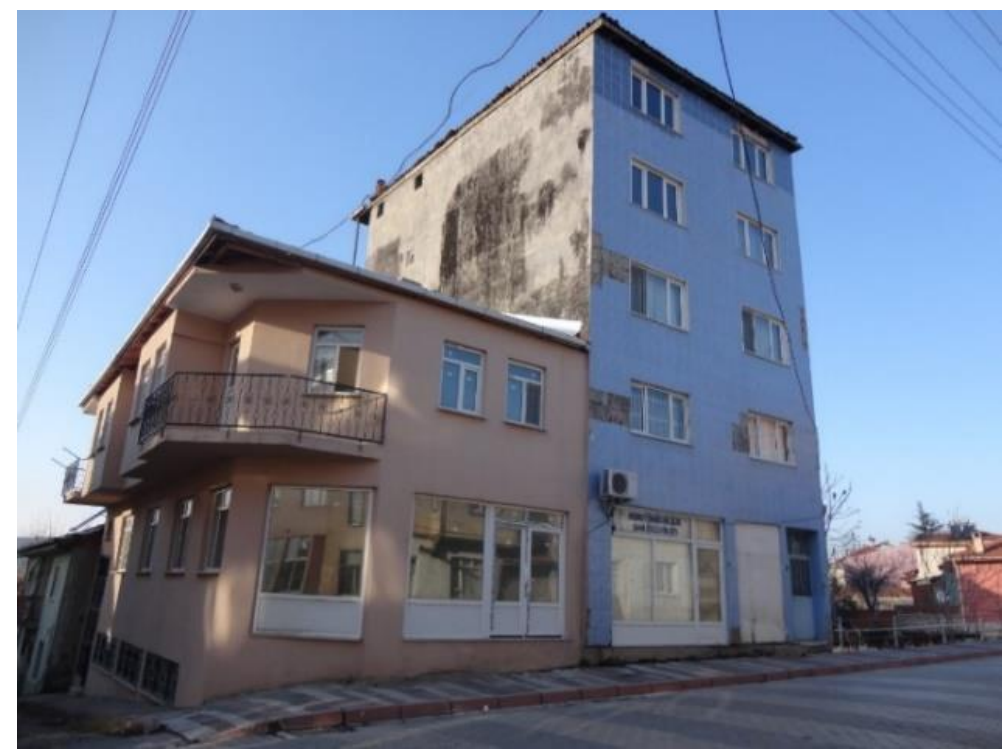

Şekil 29: Remzi Bey Konağı’nın karşısındaki yapılar (Güneş Kaya Arşivi, 2017).

Tarihi dokularda bozulmalara neden olan en yaygin sorunlar insan kaynaklıdır. Bu bozulmalar tahribat, yıkım ve terke bağlı olarak doğa koşullarının meydana getirdiği yıpranma ile tekil ölçekten başlayarak tüm dokuyu zedelemektedir (Şekil 30). Orhaneli ilçe merkezi ölçeğinde geleneksel parselsokak ilişkisi günümüze korunmuş olarak ulaşsa da gabari anlamında değişmiştir. Bu değişimin nedeni; yapılarını kaybeden, kaybetmek üzere olan veya evlerini yenilemek isteyen ailelerin geniş bahçeler içindeki mütevazı konutlarını günümüz betonarme apartmanlarına dönüştürmesidir. Geleneksel konutlar hem mekansal hem de konfor açısından yetersiz kaldığı için bu yönteme başvurulmaktadır (Şekil 31).
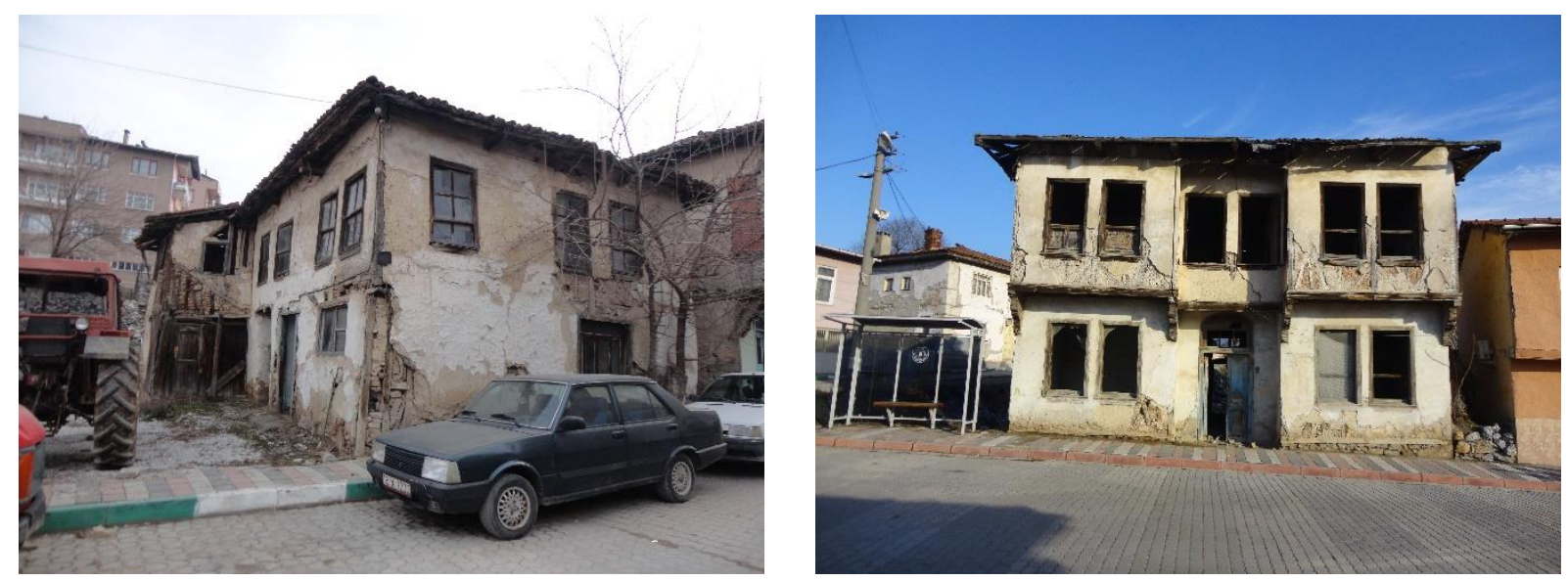

Şekil 30: Terk nedeniyle tahrip olan tescilli yapı örnekleri (Güneş Kaya Arşivi, 2017). 

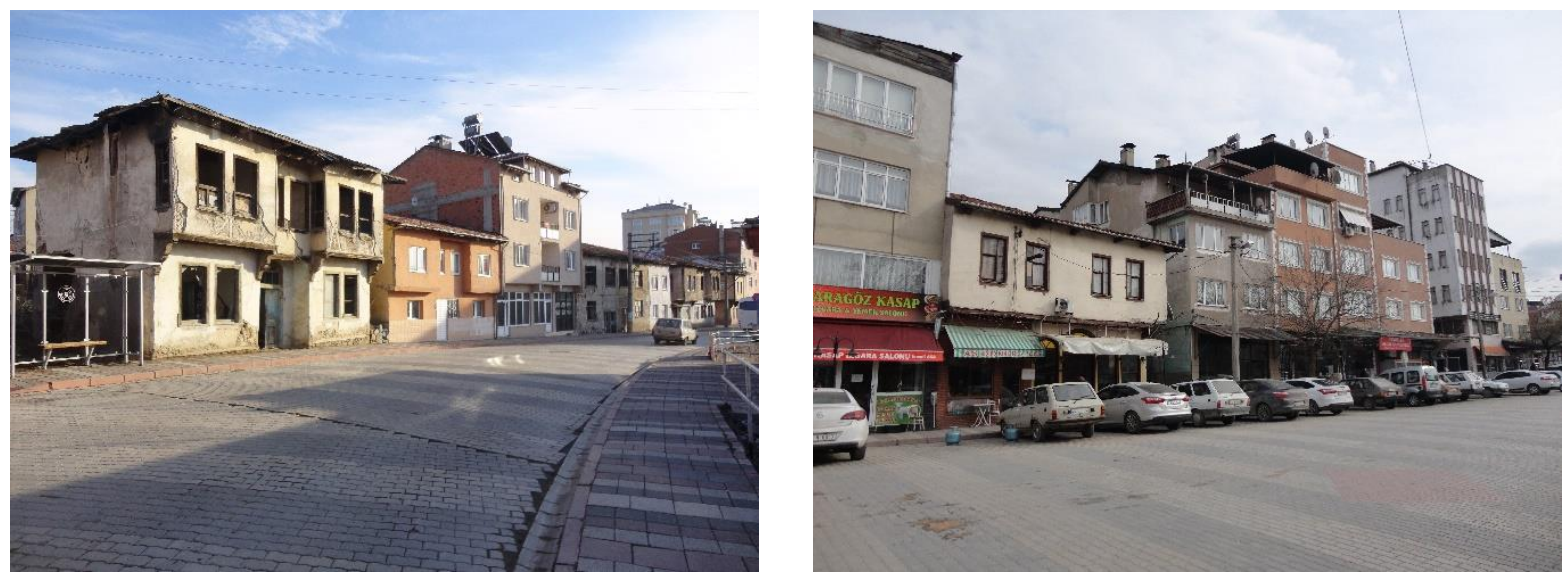

Şekil 31: Geleneksel dokuda gabari artışı örnekleri (Güneş Kaya Arşivi, 2017).

Remzi Bey Konağ1 tekil bir örnek teşkil etmekle beraber zaman içinde, büyüyen ailenin ihtiyaçları doğrultusunda parselde yol boyunca siralanan bir konut grubuna dönüşmüştür. Mevcut kullanıcıların yapılarını yıkarak yeniden çağdaş koşullarda inşa etmek yerine küçük onarımlar ile ayakta tutmaya çalışmaları sayesinde tek bir yapı değil bir doku yaşamaya devam edebilmektedir.

Yapıların terk edilmesi, yok olması ve yerlerini dokuyla uyumsuz yapılara bırakmaları dışında; konutun kullanımı da koruma sorunlarına neden olabilmektedir. Konfor koşullarını yükseltmek amacıyla çağdaş malzemelerin birer niteliksiz eke dönüşmesi ve basit onarımların yap1 malzemelerine hem strüktürel hem de görsel anlamda zarar vermesi yerleşimde yaygin bir durumdur. Örneğin birtakım bakım-onarım çalışmaları kapsamında yenilenen doğrama gibi yapı elemanları, özgünden uzak plastik, metal gibi malzemelerle tamamlanmaktadır. Bu işlem yapılırken açıklık boyutlarının da değiştirilmesi zaman zaman söz konusudur ki; özgün cephe biçimlenişiyle beraber yapının taşıyıcı sistemi de zarar görmektedir. Remzi Bey Konağı'nda görüldüğü gibi yapının açıklık boyutlarını koruyarak sadece yapı elemanı değiştirmek, yapının okunurluğunun devamı bakımından olumlu sayılabilir. Batı cephesinde özgün çift kanatlı ana giriş kapısının kapatılarak yerine düzensiz ve muhdes pencereler konulmas1, Remzi Bey Konağı'nda hem estetiği bozmas1 hem de yanlış bilgi vermesi sebebiyle sorun teşkil etmektedir.

Konutlardaki çanak anten, fayans, çimento gibi uygulamaların geleneksel görünümü bozmasının yanında, uygulanan malzemelerden bazıları uzun vadede yapı malzemelerinin iç dengesine zarar vermektedir. Söz konusu yapıda konfor koşullarını iyileştirmek ve yapıyı kullanabilmek adına çağdaş fakat özgün yapının bünyesi ile uyumsuz malzemelerin kullanıldığı görülmektedir. Banyolardan biri özgün yapı sınırının dışında, yapıya eklemlenmiştir. İçerideki ıslak hacimler ise en azından tesisat birliği sağlanacak şekilde yapı içinde en az dağılım ile konumlandırılmaya çalışılmıştır. Ancak ahşap strüktürlü, ahşap zemin ve tavan kaplamalı tarihi konağa uzun zaman önce getirilen bu sistem ve tesisatların uygun olmadığı açıktır. Yapının kullanımının sürebilmesi için mekanların dışarı çıarılması teklif edilemez. Çözüm olarak; gelişen teknolojinin sunduğu, daha hafif, ahşap hammaddeli malzemeler ile banyo ve mutfakların yenilenmesi önerilebilir. Bu şekilde yapının iç dengesi malzeme yönünden korunmuş olacaktır. 
Konağın yanındaki yapılar aile üyeleri arasında paylaşılarak genellikle yılın belirli zamanlarında kullanılmaktadır. Ana yapının sürekli ve dönemsel kullanıcıları ise, günümüzde kişi sayısının oldukça azalması nedeniyle mekanlarını verimli kullanamamaktadır. Doğu-batı doğrultusundaki duvar ile yapı ikiye ayrıldığında, sofadan kalan alanlar küçük mekanlara dönüştürülerek değerlendirilmiştir. Yer yer çok küçük alanlarda mekanlar çözülmeye çalışılmıştır (ör. depo, tuvalet vb). Mekanların, ortadaki bölücü duvar yerinde bırakılsa bile, yalnızca diğer özgün duvarlar kalacak şekilde yeniden düzenlenmesi; kullanım açısından daha konforlu bir hayat sunacaktır. Bunun yanında eklerin getirdiği yükler yapıdan alınacak ve özgün şema ortaya çıkacaktır.

Yapının zemininde görülmeyen ancak çatısında büyük bir soruna dönüşmek üzere olan su kaynaklı bozulmalar gündemdedir (Şekil 32). Çatının uygun şekilde aktarılamaması, oluşan rutubet nedeniyle özellikle birinci kattaki bezemeli ahşap tavana sahip odalar için tehlike arz etmektedir. Günümüzde düzensiz aralıklarla basit onarım yapılarak yapı yaşatılmaya çalışılmaktadır.
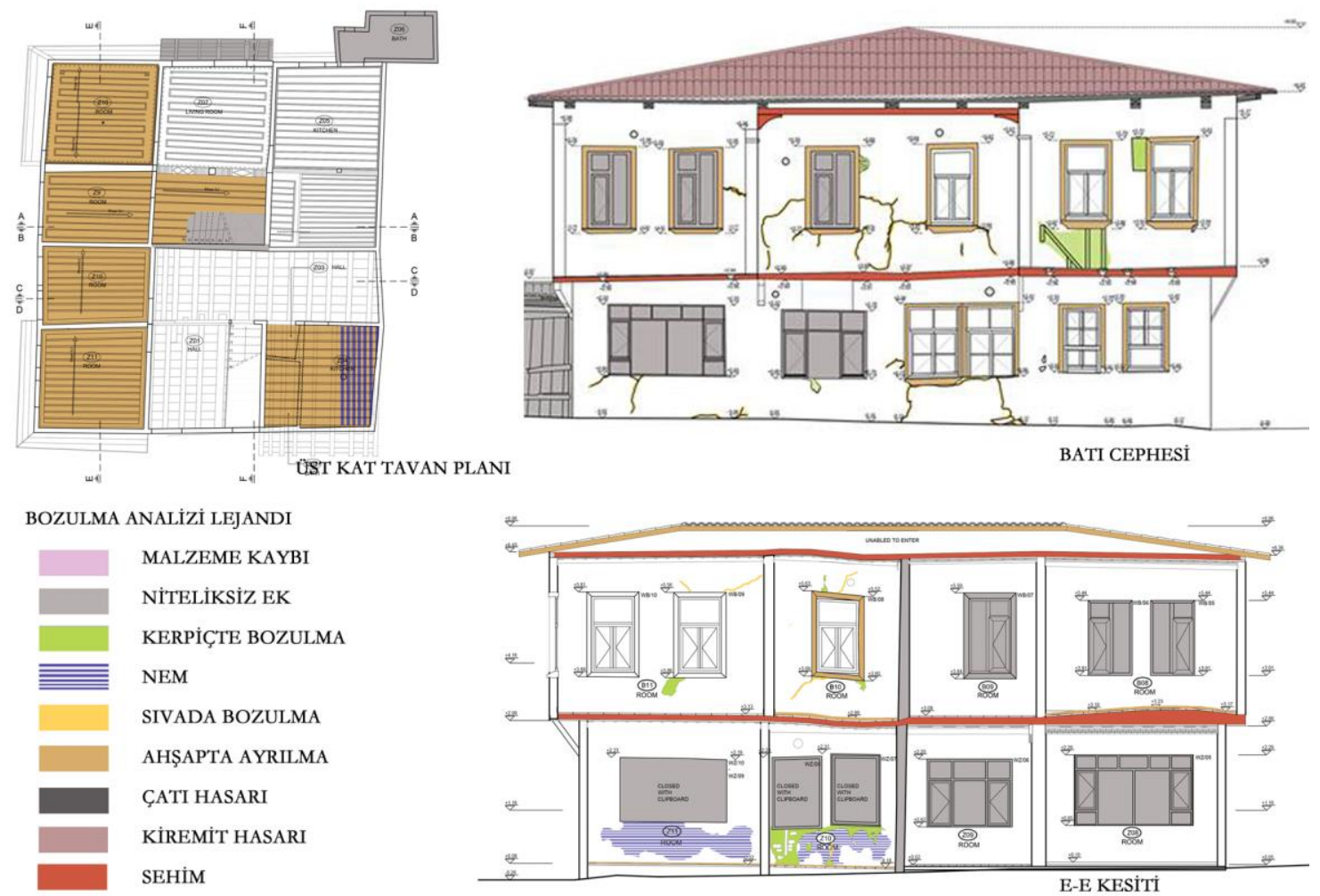

Şekil 32: Remzi Bey Konağı’nın bozulma analizi örnekleri (GTÜ Restorasyon Arşivi, 2017).

Kalın yığma duvarların bulunmaması nedeniyle mekanlarda ocaklar mevcut değildir. Dolayısıyla 1sınma sorunu ilk zamanlar mangal, sonrasında ise soba ile çözülmüştür. Soba ile 1sınma sisteminin özgün planlamada yer almaması nedeniyle, soba delikleri ve soba bacaları da yapıya sonradan eklenen öğeler olup özgün değildir. Çok sayıdaki soba delikleri, yapının cepheleriyle ilgili önemli müdahalelerdir. Cepheyi etkileyen diğer değişiklikler de muhdes eklerdir. Konağın doğu cephesine cephe boyunca uzanan tek katlı betonarme yapı ile kuzey cephe girişinin sol yanındaki oluklu levha saçak, ayıklanması gereken niteliksiz eklerdir. 
Yerleşimde değişen doluluk-boşluk oranlarının sebebi ise, neredeyse tüm yapıları yok eden yangın değil, yakın zamanlarda hızla artan apartmanlardır. Zira 1922'de Yunan işgalinin bitişinde yaşanan yangindan (Dikmen, 2012, s.23-31) sonra halk; en rahat temin edebileceği malzemelerle -ki taş, ahşap ve kerpiç-, mevcut yapı temelleri üzerine, yanan ve/veya yok olan yapısına benzer kimlikli yapılar inşa etme yoluna gitmiştir. Çünkü hem yapıların hızlı inşa edilmeleri gerekmektedir, hem de yaşam tarzı değişmemiştir. Ancak günümüzde geleneksel yapıların yerlerini alan betonarme apartmanlar özellikle gabari anlamında Orhaneli yerel kimliğini bozarak yerelliğin dışına çıkarmış ve ilgi çekiciliğini yok edip sıradanlaştırmıştır. Artan nüfus ve konut ihtiyacı da üçüncü boyuttaki sözü geçen bozulmayı tetiklemiştir. Gabarinin hızlı bozulmasında bir diğer önemli etken de mülkiyet parçalanması ile mülkiyet sayısının çoğalmasıdır. Çok katlı yapılaşmanın da aynı sonucu doğurduğu Orhaneli'de, kaçınılmaz olarak dönüşüm söz konusu olsa bile en azından yerleşim merkezindeki özgün doku ile ilişkili parsellerde mahal sayılarını sabit tutmaya çalışılmalıdır. Zira artan konut ihtiyacını karşılamak için, eski yerleşimin çeperlerinde yeni mahalleler de kurulmuştur. Apartmanlaşma sürecini yerel malzeme temininin zorlaşmasının mı, yoksa değişen yaşam alışkanlıklarının mı hızlandırdığı sorusunun cevabı ise başka bir araştırma konusudur.

Bir süredir üzerinde çalışılan Orhaneli Koruma Amaçlı İmar Planı 2018 yılında onaylanmış, ancak yerleşimin tamamına değil sadece kentsel sit alanı olarak tescillenen alana yönelik hazılanmıştır. Bu nedenle çalışmada ele alınan Remzi Bey Konăğ’nın çevresi, Orhaneli İmar Planı maddelerine tabidir. Orhaneli Koruma Amaçlı İmar Planı'nda ortaya konulan prensipler yalnızca kentsel sit alanını kapsamakla birlikte, yerleşim genelindeki tescilli yapıların çevrelerini kapsayacak şekilde genişletilmesi gerektiğine işaret etmektedir. Çünkü yürürlükteki imar planı kararlarının uygulanması, yukarıda bahsedildiği gibi hem kentsel sit alanını hem de yerleşim genelini tarihi ve geleneksel yapılar ile uyumsuz hale getirmiştir. Tarihi çevrede yeni yapılaşmada geleneksel çevre verileriyle bağlantı kurularak tasarım yapılması önerilmektedir. Öncelikle kentsel sit alanı olmak üzere kent genelindeki geleneksel konut kullanıcılarının muhafaza edilmesinin gerekliliği de Plan'ın altını çizdiği noktalardandır (Bursa Kültür Varlıklarını Koruma Bölge Kurulu, 2018). Bu nedenle gelecekte köklü değişikliklerden, ekonomik gereklilikler izlenirken bile, geçmiş ile bağların korunması adına kaçınılmalıdır.

\section{SONUÇ (CONCLUSION)}

Remzi Bey Konağı, Orhaneli İlçesi’ndeki belgeleme çalışmalarının yürütüldüğü pek çok yapıdan sadece biridir. Tek bir yap1 olmasına rağmen boyutları, inşa teknikleri, mütevazı bezemeleri ve geçmişiyle; Orhaneli'deki sosyal ve fiziksel dönüşüm süreci hakkında oldukça aydınlatıcıdır.

Tüm sözü edilen çıkarımlar sonucunda; yeniden inşa sürecinde Remzi Bey ihtiyacı doğrultusunda önce yanan hanın yerine o gün için gerekli olan konutunu, han temelleri üzerine yine yerel malzemelerle ve geleneksel yapım sistemiyle inşa ettirmiştir. Zaman içinde, genişleyen ailenin barınması için Zafer Caddesi boyunca sıralanan diğer konutlar eklenmiştir. Parsel boyutunda doluluk oranı ihtiyaç doğrultusunda artmıştır. Parseldeki yeni yapılar ilk yapı boyutunda olmasalar bile, Remzi Bey Konağı ile benzer kimliktedir. Burada olumlu olarak, plan bazında görülen doluluk artışı gabaride görülmemektedir. Fakat bir diğer tespit olan artan kullanıcı sayısı ve beraberinde gelen mülkiyet artısı, yapı özelinde ortaya çıkmaktadır. Mülkiyet arışı aynı zamanda tescilli yapıya 
gerekli müdahale ve onarımların yapılmasını zorlaştırmaktadır. Çatıdaki su sorununun doğru şekilde çözülebilmesi, cephenin özgüne uygun düzenlenmesi gibi iyileştirmelerin yapılabilmesi için, tescilli Remzi Bey Konağı'nın projelerinin hazırlanması, Bursa Kültür Varlıklarını Koruma Bölge Kurulu'nda onaylanması ve projeye uygun müdahalesi gerekmektedir. Özgün kullanıcılarını kaybetmemiş olması ise, Remzi Bey Konağı'nın yaşamını hem fiziki varlı̆ğ ile hem de kimliğini kaybetmeden sürdürmesinin en önemli nedenidir.

Dünya mimarlık mirasının öğesi olan, insanlık tarihi için önem taşıyan anıtların aynen korunması gerektiğini söyleyen hem uluslararası belgeler, hem de başta 2863 sayılı Kültür ve Tabiat Varlıklarını Koruma Kanunu olmak üzere, ilgili Türkiye yasaları, sadece bulundukları çevre için anlam taşıyan ve yöreye karakter veren 2. grup yapıların onarımlarında ise daha serbest davranılmasina izin verilebileceğinin altını çizmektedir (Ahunbay, 2014: 31-36). Bu çerçevede belirli bir konforu hedeflemek veya alışılan çevreden kopmamak bağlamında yeni yapılaşmalar makul ve hatta olması gereken isteklerdir. Ancak bunu sağlamaya çalışırken içinde bulunulan yerel dokunun yapı, arsa ve gabari ölçeğindeki doluluk-boşluk oranları ile yaşam tarzı değişimlerinin uzun vadede sosyal, kültürel ve çevresel kayıplara neden olacakları unutulmamalıdır. Bu olumsuzluklara meydan vermeyen ve kısıtlı imkanlar ile kullanımına devam edilen Rezmi Bey Konağı, boyutsal anlamda büyüklügüne rağmen yaşatılabilmektedir. Üstelik Remzi Bey Konağ1 gibi yapıların oluşturduğu doku, Orhaneli'nin kaybolmaya başlayan hafizasının değerli öğeleridir. Ana cadde üzerinde yer almasından dolayı aynı zamanda ilçenin değerli geleneksel konutlarından da biri olan yapı, plan şemasının farklılığı ile de geçmişin çeşitliliğine referans vermektedir. Yapıya hala konut olarak sahip çıkan kullanıcılarına destek olunmalı, yapının verdiği referansların doğru kalması ve mimari niteliklerinin iz sürmeye gerek kalmadan okunması sağlanmalıdır. 


\section{REFERANSLAR (REFERENCES)}

Ahunbay, Z. (2014). Taribi Çevre Koruma ve Restorasyon. İstanbul: YEM.

Bursa Büyükşehir Belediyesi Meclis Karar1, Karar no: 2022. Kabul Tarihi: 26.07.2018. Orhaneli Yuldı Havu₹u Meydan ve Cevresi Kentsel Sit Alam Koruma Amaçh Uygulama Imar Planı.

Cemiloğlu, M. (2005). “Bursa Bölgesi Yörükleri”. C. Çiftçi (yay.), Osman Gą̨i ve Bursa Semposyumu "Payitaht Bursa'nn Kültürel ve Ekonomike İliskileri”" Bildiri Kitabr, 4-5 Nisan 2005, Bursa. Bursa: Osmangazi Belediyesi, 35-49.

Delil, H. ve Dinçel, Ö.F. (2013). Hüdavendigar Vilayeti Salname-i Resmisi H.1325-M.1907. Bursa: Bursa İl Özel idaresi.

Dikmen, A. (2011). Gelenek ve Innançlaryyla Uludağ’n Arka Yürü. Bursa: Bursa Büyükşehir Belediyesi.

Dikmen, A. (2012). Sosyal ve Kültürel Değerleriyle Orbaneli. İstanbul: Akmat Akınoğlu.

Eldem, S. H. (1954). Türk Evi Plan Tipleri. İstanbul: İTÜ.

Emecen, F. (1998). Hudâvendigâr. TDV İslam Ansiklopedisi içinde Cilt 18 (s. 285-286). İstanbul: Türkiye Diyanet Vakfi.

Eres, Z. (2013). Türkiye’de Geleneksel Kırsal Mimarinin Korunmasi: Tarihsel Süreç, Yasal Boyut. K. K. Eyüpgiller ve Z. Eres (der.) Mimari ve Kentsel Koruma Prof. Dr. Nur Akın'a Armağan. İstanbul: YEM Yayın, 439-451.

Gebze Teknik Üniversitesi (GTÜ) Mimarlık Fakültesi Restorasyon Arşivi (2016-2017).

Gülbay, O. (2009). Anadolu'da İmparator Hadrianus dönemi imar faaliyetleri. (Yayınlanmamış Doktora Tezi). Dokuz Eylül Üniversitesi, Sosyal Bilimler Enstitüsü, İzmir.

Güneş, Z.S. (2015). Yayımlanmamış Yüksek Lisans Tezi. Bursa Deliballlar Köyü sit koruma projesi: koruma çalışmalar için ön koşul ve ilkelerin araștrrlması. (Yayımlanmamış Yüksek Lisans Tezi). İstanbul Teknik Üniversitesi, Fen Bilimleri Enstitüsü, İstanbul.

Güneş, Z. S. (2018). Pekmezciler Evi. TAÇ Mimarlı Arkeoloji, Kültür ve Sanat Dergisi, 10, p.34-39.

Kaplanoğlu, R. (2010). "Kuruluş Döneminde Bursa Çevresindeki Kaleler Ve Yerleşim Yerleri”. Y. Oğuzoğlu (haz.), Osman Gaz̨i ve Dönemi Bildiri Kitabı, 9-10 Nisan 2010, Bursa. İstanbul: Kayhan, 138-166.

Kültür ve Tabiat Varlkelarmı Koruma Kanunu. Alındığı yer http://www.mevzuat.gov.tr/MevzuatMetin/1.5.2863.pdf

Onur, F. (2011). New Inscriptions From Hadrianoi Pros Olympon (Mysia). OLBA, 19, p. 331348.

Schwertheim, E. (2014). Hadrianoi'nin Tarihi Coğrafyası. (çev. İ. H. Mert), Bursa ve İlçeleri Arkeolojik Kültür Envanteri-I. Bursa: Akmat, 11-19.

Şahin, M. (2014). Bursa’nın Dă̆ İlcelerinin Taribi ve Kültürel Mirası Envanteri. Bursa: Pozitif. 
Şahin, M., Mert, İ.H. ve Şahin, D. (2011). "Bursa ve Çevresi Yüzey Araştırması-2009-Keles ve Orhaneli”. A. N. Toy ve C. Keskin, (yay.), 28. Araştırma Sonuçlar Toplantısı c.1, 24-28 Mayıs 2010, İstanbul. Ankara: Allame, 99-114.

Topçu, N. (2004). 1521 Tarihli Tımar Deferi’ne Göre; XVI. Yüzyıl Başlarında Dağ Yöresi (Orhaneli, Keles, Harmancık, Büyükorhan). Bursa Arastırmalar Dergisi, 2, p.31-35.

Topçu, N. (2009). Atranos'tan Orhaneli-Beyce'ye. Güney Bursa Dăg-Der Yardimlaşma ve Kültür Derneği Aylhk Yerel Kültür Dergisi, 5, p.14-15.

KK1: Fatma Kazanç, iletişim tarihi: 05.10.2016.

KK2: İsmail Hakk1 Güneş, iletişim tarihi: 25.06.2017.

\section{YAZARLARIN BİYOGRAFİSİ (BIOGRAPHY OF THE AUTHORS)}

\section{Z. Sena GÜNEŞ KAYA}

1989 Bursa doğumlu olan Güneş Kaya, ilk, orta ve lise öğrenimini İstanbul'da tamamlamıştır. Yıldız Teknik Üniversitesi Mimarlık Fakültesi Mimarlık Bölümü'nden 2012 yllında mezun olmuş, İstanbul Teknik Üniversitesi Fen Bilimleri Enstitüsü Restorasyon Programı kapsamında hazırladığ1 "Bursa Deliballılar Köyü sit koruma projesi: Koruma için ön koşul ve ilkelerin belirlenmesi” başlıklı yüksek lisans tezi ile 2015 yılında yüksek mimar ünvanını almıştır. Aynı program dahilinde ve Yıldız Teknik Üniversitesi Mimarlık Tarihi ve Kuramı Programı'nda doktoralarını sürdürmektedir. İstanbul Üniversitesi Mimarlık Fakültesi’nde araştırma görevlisi olarak görev yapmaktadır.

\section{Elif Özlem AYDIN}

1993 yılında İTÜ. Mimarlık Fakültesi'nden mezun olan Elif Özlem AYDIN, 1996 yılında İTÜ. Fen Bilimleri Enstitüsü’nde yüksek lisansını tamamlamıştır. Çeşitli mimarlık bürolarında çalıştıktan sonra 1998 yllında Uludağ Üniversitesi, Mimarlık Fakültesi'nde göreve başlayan AYDIN, 2002 yılında Gebze Teknik Üniversitesi Mimarlık Fakültesi'ndeki görevine atanmıştır. AYDIN, İTÜ Fen Bilimleri Enstitüsü'nde 2004 yılında tamamladığ1 “Bursa'daki İpek Fabrikaları ve İpekçilikle İlgili Endüstri Mirasının Korunması” başlıklı doktora çalışmasıyla Türkiye Mimarlık Vakfı Enstitüsü 2005 yılı Restorasyon bilim dalı ve European Union Prize for Cultural Heritage/Europa Nostra Awards 2006 ödüllerine layık görülmüştür. G.T.Ü.'de Prof. Dr. olarak görevine devam eden AYDIN tek yapı koruma, kentsel koruma ve endüstri mirası konularında akademik çalışmalarını sürdürmektedir. Mimarlık tarihi araştırmaları, tespit-rölöve, koruma teknik ve yöntemleri konularında 70'e yakın bilimsel araştırması bulunmaktadır. 2010 yılından beri Kocaeli Kültür Varlıkları Koruma Bölge Kurulu üyesidir. Iyi derecede İngilizce bilmektedir. Evli ve iki çocuk annesidir. 